\title{
GENERATION OF CATALYSTS BY PHOTOLYSIS OF TRANSITION METAL COMPLEXES
}

\author{
Mark S. Wrighton, D. S. Ginley, M. A. Schroeder and D. L. Morse
}

\author{
Department of Chemistry, Massachusetts Institute of Technology, \\ Cambridge, Mass. 02139, USA
}

\begin{abstract}
The concepts of photocatalysis and photoassistance are defined and recent experimental results involving transition metal carbonyls as photocatalysts and photoassistance agents are described. Photolysis of $\mathrm{Fe}(\mathrm{CO})_{5}$ is shown to lead to olefin hydrogenation under mild conditions $\left(\mathrm{H}_{2} 1 \mathrm{~atm}, 25^{\circ}\right)$, and $\mathrm{d}^{8} \rightarrow \mathrm{d}^{6}$ oxidative addition to photogenerated coordinatively unsaturated iron carbonyl intermediates is shown to be a possible pathway both for hydrogenation and olefin isomerization. Olefin isomerization, hydrogenation, and hydrosilation via photolysis of $\mathrm{Cr}(\mathrm{CO})_{6}, \mathrm{Mo}(\mathrm{CO})_{6}$. and $\mathrm{W}(\mathrm{CO})_{6}$ are also described. and $\mathrm{d}^{6} \rightarrow \mathrm{d}^{4}$ oxidative additions to photogenerated coordinatively unsaturated intermediates are invoked to account for the olefin activations. Photoisomeriza-

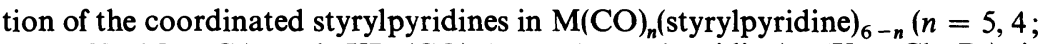
$\mathrm{M}=\mathrm{W}, \mathrm{Mo}, \mathrm{Cr})$ and $\mathrm{XRe}(\mathrm{CO})_{3}$ (trans-4-styrylpyridine $)_{2}(\mathrm{X}=\mathrm{Cl}, \mathrm{Br})$ is discussed in terms of model photoassistance situations. Metal-metal bond cleavage is shown to dominate the photochemistry of the compounds $\mathrm{M}_{2}(\mathrm{CO})_{10}$ $(\mathrm{M}=\mathrm{Mn}, \mathrm{Re}), \mathrm{Mn}_{2}(\mathrm{CO})_{9} \mathrm{PPh}_{3}, \mathrm{Mn}_{2}(\mathrm{CO})_{8}\left(\mathrm{PPh}_{3}\right)_{8}$, and $\left[\mathrm{h}^{5}-\mathrm{C}_{5} \mathrm{H}_{5} \mathrm{M}(\mathrm{CO})_{3}\right]_{2}$ $(\mathrm{M}=\mathrm{Mo}, \mathrm{W})$. The resulting mononuclear metal fragments react efficiently with other photogenerated metal fragments, $I_{2}$ or alkyl halides.
\end{abstract}

\section{INTRODUCTION}

We define the term photocatalysis to be the photogeneration of a catalyst from a thermally inert precursor such that substrate transformations result which are both catalytic with respect to the number of photons absorbed and with respect to the actual catalyst. Photocatalytic systems such as that shown in Scheme I are the subject of this paper. For Scheme I the following points are to be noted: (1) the only excited state chemistry is the primary act of catalyst formation; (2) the catalyst which is generated behaves as a thermal

$$
\begin{gathered}
\text { Metal complex } \stackrel{h v}{\rightarrow}[\text { Catalyst }] \\
\text { Metal complex }+ \text { Substrate } \stackrel{\Delta}{\rightarrow} \text { No reaction } \\
[\text { Catalyst }]+\text { Substrate } \stackrel{\Delta}{\rightarrow} \text { Transformed substrate }+ \text { [Catalyst }] \\
{[\text { Catalyst }] \stackrel{\Delta}{\rightarrow} \text { Poisoning }}
\end{gathered}
$$

Scheme I 
catalyst thereby leading only to thermal reactions of the substrate; and (3) the catalytic action begins only upon photolysis and continues after cessation of photolysis until poisoning processes have removed or inhibited the catalyst.

Investigation of photocatalytic systems such as that shown in Scheme I has merit for several reasons. First, since the process involving catalyst formation is an excited state decay, the catalyst, at least in principle, can be unique, i.e. the catalyst may be inaccessible by thermal routes and may be superlative with respect to rate, specificity, lifetime, etc. compared to catalysts generated thermally. Herein lies the interest to chemists. In more practical terms, these systems will provide a large number of reactions which are economical with respect to the light since the quantum yield for substrate transformation exceeds unity. The catalytic activity is photoinitiated and as a consequence there exists the potential for control of catalytic action by turning on and off the light source. Further, when catalytic action is photoinitiated one may apply the reactions to imaging devices. Finally, study of photoeffects in catalytic systems may lead to a deeper understanding of catalysis in a very general way.

We find, empirically, that continuous photolysis accelerates many photocatalytic reactions, and in many cases we find no measurable substrate transformation without continuous photolysis. The term photoassisted is reserved for substrate transformations which appear to proceed according to Scheme I but which require continuous photolysis. As in all stoichiometric photoreactions one hopes that the novel chemistry obtained will outweigh the disadvantages of the technique. Photoassisted substrate transformations, along with photosensitization, provide good examples of photochemistry by indirect excitations.

Our major thrust has been directed towards photocatalysis, at ambient conditions, of olefin reactions such as isomerization, dimerization, hydrogenation and hydrosilation. A large number of transition metal complexes are known to homogeneously catalyse these reactions and all systems have mechanistic aspects in common ${ }^{1}$. The three general steps of catalytic transformations are shown in Scheme II. As indicated the three steps of the

$$
\begin{gathered}
{[\text { Catalyst }]+\text { Substrate }-\stackrel{\Delta \text { or } h v}{\longrightarrow}[\text { Catalyst-Substrate }]} \\
{[\text { Catalyst-Substrate }] \stackrel{\Delta \text { or } h v}{\longrightarrow}[\text { Catalyst-transformed substrate }]}
\end{gathered}
$$

[Catalyst-transformed substrate] $\stackrel{\Delta}{\text { or }} \underline{h v} \rightarrow[$ Catalyst $]+$ Transformed substrate

Scheme II

cycle can either be photochemical or thermal and the relative importance of these activation pathways will be a complex function of thermal rates, quantum yields, concentration of the intermediates and their molar extinction coefficients, and the detailed mechanism involved in each step. Nonetheless, the fact that these three steps can be photochemical provides a reasonable rationale for photoassisted reactions and photoaccelerated thermal catalysis. 


\section{CATALYSTS BY PHOTOLYSIS OF TRANSITION METAL COMPLEXES}

Implicit in Schemes $I$ and $I I$ is the notion that there exist photoreactions of metal complexes which proceed as indicated (either yielding a catalyst or accelerating the steps of the catalytic cycle). At the present time much qualitative information is known regarding the reaction chemistry subsequent to photoexcitation of coordination compounds ${ }^{2}$. Primary photoprocesses include redox reactions, ligand substitution, intraligand reactions, and cleavage of direct metal-metal bonds. These photoreactions either are important in known photoassisted and photocatalysed reactions or have the potential to be so. We now describe the results of some investigations of the use of metal carbonyls as photocatalysts and photoassistance agents for olefin reactions.

\section{RESULTS AND DISCUSSION}

\section{(a) Photoassisted cis-trans isomerization of styrylpyridines}

Studies of primary photoreactions of metal complexes which involve ligand rearrangements are rare, perhaps, in part, due to the difficulty in preparing pure samples of interesting complexes. We have begun the study of photoprocesses in metal carbonyl-styrylpyridine complexes in comparison to their pyridine analogues. The successful synthesis of such complexes is pedestrian as we can draw on the general routes for preparation for substituted metal carbonyls ${ }^{3}$, and for many metal carbonyls the pyridine substituted derivatives are known and are thermally inert at $25^{\circ} \mathrm{C}$. The aim here is to outline some of the essential photochemical results for tungsten and rhenium carbonyls ${ }^{4}$.

Table 1. Photoreaction quantum yields for pyridyl complexes of tungsten and rhenium ${ }^{\mathrm{a}}$

\begin{tabular}{|c|c|}
\hline Reaction & $\Phi$ \\
\hline $\mathrm{W}(\mathrm{CO})_{5}(\mathrm{py}) \underset{1-\text { pentene }}{\longrightarrow} \mathrm{W}(\mathrm{CO})_{5}(1$-pentene $)$ & $0.63^{b}$ \\
\hline $\mathrm{W}(\mathrm{CO})_{5}(t-4) \longrightarrow \mathrm{W}(\mathrm{CO})_{5}(c-4)$ & $0.49^{b}$ \\
\hline $\mathrm{W}(\mathrm{CO})_{5}(t-4) \underset{1 \text {-pentene }}{\longrightarrow} \mathrm{W}(\mathrm{CO})_{5}(1$-pentene $)$ & $0.16^{\mathrm{b}}$ \\
\hline $\mathrm{W}(\mathrm{CO})_{5}(c-2) \longrightarrow \mathrm{W}(\mathrm{CO})_{5}(t-2)$ & $0.31^{\mathrm{b}}$ \\
\hline $\mathrm{W}(\mathrm{CO})_{5}(t-2) \longrightarrow \mathrm{W}(\mathrm{CO})_{5}(c-2)$ & $0.08^{b}$ \\
\hline $\mathrm{W}(\mathrm{CO})_{5}(t-2) \underset{1-\text { pentene }}{\longrightarrow} \mathrm{W}(\mathrm{CO})_{5}(1$-pentene $)$ & $0.16^{\mathrm{b}}$ \\
\hline $\mathrm{W}(\mathrm{CO})_{4}(t-4)_{2} \longrightarrow \mathrm{W}(\mathrm{CO})_{4}(t-4)(c-4)$ & $\leqslant 0.002^{b}$ \\
\hline $\mathrm{ClRe}(\mathrm{CO})_{3}(t-4)_{2} \longrightarrow \mathrm{ClRe}(\mathrm{CO})_{3}(t-4)(c-4)$ & $0.5^{\mathrm{c}}$ \\
\hline $\mathrm{BrRe}(\mathrm{CO})_{3}(t-4)_{2} \longrightarrow \operatorname{BrRe}(\mathrm{CO})_{3}(t-4)(c-4)$ & $0.5^{\mathrm{c}}$ \\
\hline
\end{tabular}

a $t-4$ is trans-4-styrylpyridine; $t-2$ is trans-2-styrylpyridine; $c-4$ is cis-4-styrylpyridine, $c-2$ is cis-2-styrylpyridine; py is pyridine; data are from refs 5,8 .

b $436 \mathrm{~nm}$.

c $366 \mathrm{~nm}$.

A comparison of the photochemistry of the $\mathrm{W}(\mathrm{CO})_{5} \mathrm{X}(\mathrm{X}=$ pyridine, trans-2-styrylpyridine, and trans-4-styrylpyridine) complexes has been carried out ${ }^{5}$ and quantum yields for several reactions are given in Table 1. 
Infra-red absorption spectra in the $\mathrm{CO}$ stretching region, Table 2, confirm that all of the ligands $\mathrm{X}$ are bound to tungsten by the nitrogen of the pyridyl group. The primary quantum yield data reveal that trans-cis isomerization of the coordinated styrylpyridines accounts for a sizeable fraction of the absorbed quanta. Apparently, this ligand-localized reaction occurs at the expense of $\mathrm{W}-\mathrm{N}$ cleavage as the quantum yield for $\mathrm{W}-\mathrm{N}$ cleavage is

Table 2. The i.r. band maxima in $\mathrm{CO}$ stretching region for pyridyl complexes of tungsten and rhenium

\begin{tabular}{|c|c|c|c|c|}
\hline \multirow{2}{*}{$\frac{\text { Complex }}{\mathrm{W}(\mathrm{CO})_{5}(\text { pyridine })^{a}}$} & \multicolumn{4}{|c|}{ Infra-red bands, $\mathrm{cm}^{-1}$} \\
\hline & 2072(w) & 1933(s) & $1920(\mathrm{~m})$ & \\
\hline $\mathrm{W}(\mathrm{CO})_{5}(t-4 \text {-styrylpyridine })^{a}$ & $2072(w)$ & 1932(s) & 1917(m) & \\
\hline $\mathrm{W}(\mathrm{CO}),(t-2 \text {-styrylpyridine })^{\mathrm{a}}$ & $2072(w)$ & 1932(s) & $1918(\mathrm{~m})$ & \\
\hline cis-W(CO) $)_{4}(\text { pyridine })_{2}^{\mathrm{b}}$ & $2008(w)$ & $1884(\mathrm{~m})$ & $1866(\mathrm{~m})$ & $1826(\mathrm{~m})$ \\
\hline$c i s-\mathrm{W}(\mathrm{CO})_{4}(t-4 \text {-styrylpyridine })_{2}^{\mathrm{b}}$ & $2003(w)$ & 1884(m) & $1863(\mathrm{~m})$ & $1825(\mathrm{~m})$ \\
\hline $\mathrm{ClRe}(\mathrm{CO})_{3}$ (pyridine $)_{2}^{\mathrm{c}}$ & 2025(s) & $1920(\mathrm{~m})$ & $1885(\mathrm{~m})$ & \\
\hline $\mathrm{ClRe}(\mathrm{CO})_{3}(t-4 \text {-styrylpyridine })_{2}^{c}$ & $2020(s)$ & $1910(\mathrm{~m})$ & $1880(\mathrm{~m})$ & \\
\hline $\mathrm{BrRe}(\mathrm{CO})_{2}(t-4 \text {-styrylpyridine })_{2}^{\mathrm{c}}$ & $2020(s)$ & $1910(\mathrm{~m})$ & $1880(\mathrm{~m})$ & \\
\hline
\end{tabular}

- Isooctane solvent; ref. 5

${ }^{6} \mathrm{CHCl}_{3}$ solvent; ref. 5 .

- $\mathrm{CH}_{2} \mathrm{Cl}_{2}$ solvent; ref. 8 .

markedly lower for the styrylpyridines than for pyridine itself. Importantly, however, some photosubstitution of the styrylpyridines does occur. Lack of any photosubstitution would preclude photoassistance activity in that the reaction would be doomed to be only stoichiometric with respect to tungsten. Photosubstitution and photo-induced ligand isomerization couple to make $\mathrm{W}(\mathrm{CO})_{6}$ a photoassistance agent by the sequence (8)-(11) which is the minimum number of steps. This scheme is a model of photoassistance as a

$$
\begin{gathered}
\mathrm{W}(\mathrm{CO})_{6} \stackrel{h v}{\longrightarrow} \mathrm{W}(\mathrm{CO})_{5}+\mathrm{CO} \\
\left.\mathrm{W}(\mathrm{CO})_{5}+\text { trans-styrylpyridine } \stackrel{\Delta}{\longrightarrow} \mathrm{W}(\mathrm{CO})_{5} \text { (trans-styrylpyridine }\right) \\
\mathrm{W}(\mathrm{CO})_{5}\left(\text { trans-styrylpyridine) } \stackrel{h v}{\longrightarrow} \mathrm{W}(\mathrm{CO})_{5}\right. \text { (cis-styrylpyridine) } \\
\mathrm{W}(\mathrm{CO})_{5}(\text { cis-styrylpyridine }) \stackrel{h v}{\longrightarrow} \mathrm{W}(\mathrm{CO})_{5}+\text { cis-styrylpyridine }
\end{gathered}
$$

mode of indirect photochemistry: the free ligand does not absorb light at energies as low as the metal-ligand complex and thus the cis-trans isomerization can be achieved by irradiation at wavelengths where the ligand does not absorb. The term photoassistance is appropriate since continuous photolysis is required, and in this case it is clear that one can generate a non-thermodynamic mixture of the styrylpyridines by photolysis of $\mathrm{W}(\mathrm{CO})_{6}$ in the presence of excess styrylpyridine, since the thermodynamic equilibrium should be nearly 100 per cent trans and we find trans $\rightarrow$ cis isomerization upon photolysis of $\mathrm{W}(\mathrm{CO})_{6}$ solutions of trans-styrylpyridines. 


\section{CATALYSTS BY PHOTOLYSIS OF TRANSITION METAL COMPLEXES}

Photoassisted cis-trans isomerization of the styrylpyridines is complicated by another primary photoreaction of $\mathrm{M}(\mathrm{CO})_{5} \mathrm{X}$ leading to substitution of $\mathrm{CO}$ and formation of cis-W(CO) ${ }_{4} \mathrm{X}_{2}$. The importance of this process increases with increasing excitation energy for $\mathrm{X}=$ pyridine, aliphatic amine as shown in Table $3^{5,6}$. This is likely due to direct population of higher ligand field

Table 3. Wavelength dependence of quantum yields for $\mathrm{M}(\mathrm{CO})_{5} \mathrm{X}$ to $\mathrm{M}(\mathrm{CO})_{4} \mathrm{X}_{2}$ conversion $^{\mathrm{a}}$

\begin{tabular}{|c|c|c|c|c|}
\hline $\mathbf{M}$ & $X$ & $\Phi_{436 \mathrm{~nm}}$ & $\Phi_{405 \mathrm{~nm}}$ & $\Phi_{366 \mathrm{~nm}}$ \\
\hline Mo & $\begin{array}{l}\text { Piperidine } \\
n-\mathrm{PrNH}_{2}\end{array}$ & $\begin{array}{l}0.04_{8} \\
0.057\end{array}$ & $\begin{array}{l}0.11 \\
0.20\end{array}$ & $\begin{array}{l}0.13 \\
0.24\end{array}$. \\
\hline W & $\begin{array}{l}\text { Pyridine } \\
\text { Piperidine } \\
n \text {-PrNH }\end{array}$ & $\begin{array}{l}0.00_{2} \\
0.006 \\
0.016\end{array}$ & $\begin{array}{l}\overline{0.008} \\
0.02_{2}\end{array}$ & $\begin{array}{l}0 . n_{3} \\
0.03_{4} \\
0.05_{7}\end{array}$ \\
\hline
\end{tabular}

- Refs. 5, 6

excited states which feature population of the $d_{x^{2}-y^{2}}$ orbital which is $\sigma$-antibonding for the equatorial COs. These states do not decay completely efficiently to the lowest ligand field state which features population of the $d_{z^{2}}$ orbital which is $\sigma$-antibonding with respect to the axial ligands and empirically gives $\mathrm{M}-\mathrm{N}$ cleavage. Also note that molybdenum (and most probably chromium) carbonyls give higher yields for this process than the tungsten carbonyls. The possibility that photoassistance could continue via electronic excitation of cis- $\mathrm{W}(\mathrm{CO})_{4} \mathrm{X}_{2}$ is reasonable, but we find that cis-W(CO) 4 $^{-}$ (trans-4-styrylpyridine $)_{2}$ is essentially inert $\left(\Phi_{436 \mathrm{~nm}}<0.01\right)$ to trans-cis photoisomerization of the coordinated ligands. This of course does not rule out the possibility that the photostationary state is 100 per cent trans and that reasonable cis $\rightarrow$ trans quantum yields would be obtained. Nonetheless, we point out that $\mathrm{Cr}(\mathrm{CO})_{6}$ does not serve as a photoassistance agent, and $\mathrm{Mo}(\mathrm{CO})_{6}$ is much less effective than $\mathrm{W}(\mathrm{CO})_{6}$. This correlates with the faster

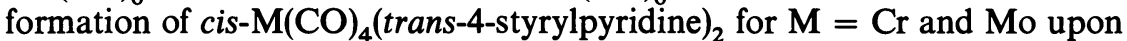
irradiation of $\mathrm{M}(\mathrm{CO})_{6}$ in the presence of trans-4-styrylpyridine. Thus, $\mathrm{Cr}(\mathrm{CO})_{6}$ and $\mathrm{Mo}(\mathrm{CO})_{6}$ are poor as trans $\rightarrow$ cis photoassistance agents because: (1) $\mathrm{M}(\mathrm{CO})_{5}$ (trans-4-styrylpyridine) gives fairly efficient $\mathrm{CO}$ substitution (precluding efficient trans $\rightarrow$ cis isomerization) and (2) the resulting cis- $\mathrm{M}(\mathrm{CO})_{4}(\text { trans-4-styrylpyridine })_{2}$ complex is relatively inert to photoisomerization of the coordinated ligands.

The dramatic difference in photosensitivity (with respect to ligand iso-

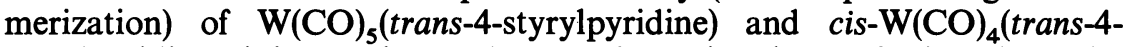
styrylpyridine $)_{2}$ is interesting, and a tentative rationale rests in the substantial differences in the nature of the lowest excited state in these $d^{6}$ complexes. Again, a comparison with $\mathrm{W}(\mathrm{CO})_{5}\left(\right.$ pyridine) and cis- $\mathrm{W}(\mathrm{CO})_{4}(\text { pyridine })_{2}$ is appropriate, Table 4 and Figure 1 . The rather large red-shift of the first absorption maximum of the bis-trans-4-styrylpyridine compared to the bis-pyridine complex suggests a more substantial contribution from $\mathbf{M}$ pyridyl CT to the lowest excited state. In the $\mathrm{W}(\mathrm{CO})_{5} \mathrm{X}$ complex such a contribution is still present but the lowest excited state apparently has much 
MARK S. WRIGHTON, D. S. GINLEY, M. A. SCHROEDER AND D. L. MORSE

more ligand field character than in the cis-W(CO) $)_{4}(\mathrm{X})_{2}$ case. At least for $\mathbf{M}=\mathbf{W}$ we do not find that photosubstitution is the alternative excited state decay path of the M-pyridyl CT excited state for cis-M $(\mathrm{CO})_{4}($ trans-4styrylpyridine $)_{2}$. The results reported recently ${ }^{7}$ for $\mathrm{Ru}(\mathrm{II})-4$-styrylpyridine complexes (which are also of the low-spin $\mathrm{d}^{6}$ configuration and where the M-pyridyl CT state is clearly lowest) show that the M-pyridyl CT state does not give efficient trans $\rightarrow$ cis isomerization while $c$ is $\rightarrow$ trans is a process occurring with high efficiency yielding highly trans-rich stationary states upon population of the CT state.

Table 4. Electronic spectral features for pyridyl complexes of tungsten and rhenium

\begin{tabular}{ll}
\hline Complex & Lowest energy bands, nm $\left(\varepsilon, 1 \mathrm{~mol}^{-1} \mathrm{~cm}^{-1}\right)$ \\
\hline $\mathrm{W}(\mathrm{CO})_{5}(\mathrm{py})^{\mathrm{a}}$ & $440(627) \mathrm{sh} ; 380(6900)$ \\
$\mathrm{W}(\mathrm{CO})_{5}(t-4)^{\mathrm{a}}$ & $408(7900) ; 316(16350)$ \\
cis-W(CO) $(\mathrm{py})_{2}^{\mathrm{b}}$ & $413(9400)$ \\
cis-W(CO) $)_{4}(t-4)_{2}^{\mathrm{b}}$ & $448(11000) ; 310(46200)$ \\
$\mathrm{ClRe}(\mathrm{CO})_{3}(t-4)_{2}^{\mathrm{c}}$ & $330(53000)$ \\
$\mathrm{Br} \operatorname{Re}(\mathrm{CO})_{3}(t-4)_{2}^{\mathrm{c}}$ & $330(53000)$ \\
$\mathrm{ClRe}(\mathrm{CO})_{3}(\mathrm{py})_{2}$ & $\sim 340(2000) \mathrm{sh} ; 295(6900) \mathrm{sh} ; 264(9000)$ \\
\hline
\end{tabular}

Isooctane solvent; ref. 5

b Benzene solvent; ref. 5 .

c $\mathrm{CH}_{2} \mathrm{Cl}_{2}$ solvent; ref. 8 .

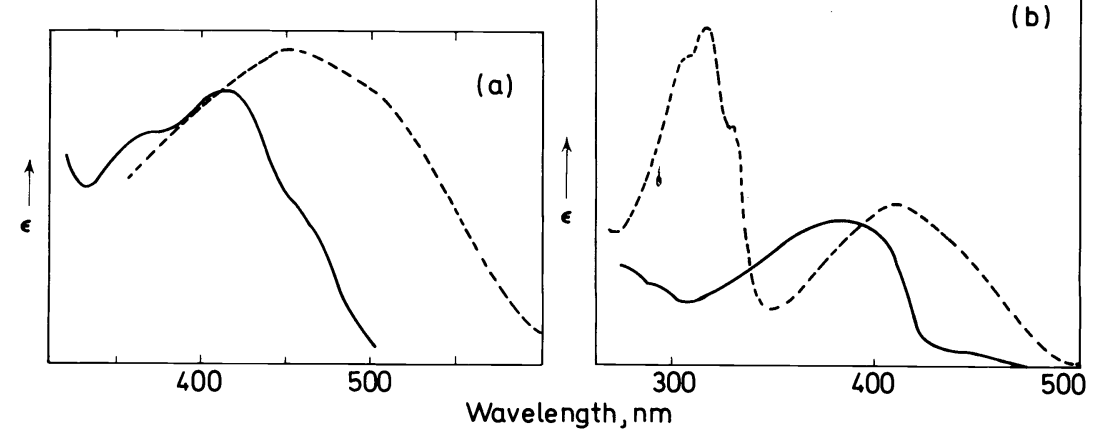

Figure 1. (a) Comparison of absorption spectra of cis-W(CO) $)_{4}$ (pyridine) $)_{2}(413 \mathrm{~nm}, \varepsilon=9400$ $\left.\mathrm{mol} \mathrm{l}^{-1} \mathrm{~cm}^{-1}\right)(-\longrightarrow)$ and cis-W(CO) ${ }_{4}$ (trans)-4-styrylpyridine $)_{2}\left(448 \mathrm{~nm}, \varepsilon=11000 \mathrm{~mol} \mathrm{l}^{-1} \mathrm{~cm}^{-1}\right)$ (----) in benzene solution at $25^{\circ} \mathrm{C}$. (b) Comparison of absorption spectra of W(CO) $)_{5}$ (pyridine) $\left(380 \mathrm{~nm}, \varepsilon=6900 \mathrm{~mol} \mathrm{l}^{-1} \mathrm{~cm}^{-1}\right)(-)$ and $\mathrm{W}(\mathrm{CO})_{5}\left(\right.$ trans $^{-4}-$-styrylpyridine $)(408 \mathrm{~nm}$, $\left.\varepsilon=7900 \mathrm{moll}^{-1} \mathrm{~cm}^{-1}\right)(----)$ in isooctane solution at $25^{\circ} \mathrm{C}$.

The results for cis- $\mathrm{M}(\mathrm{CO})_{4}$ (trans-4-styrylpyridine $)_{2}(\mathrm{M}=\mathrm{Cr}, \mathrm{Mo}, \mathrm{W})$ stand in contrast to those ${ }^{8}$ for $\mathrm{ClRe}(\mathrm{CO})_{3}$ (trans-4-styrylpyridine) ${ }_{2}$ and $\mathrm{Br} \operatorname{Re}(\mathrm{CO})_{3}$ (trans-4-styrylpyridine) ${ }_{2}$ which are also of the $\mathrm{d}^{6}$ electronic configuration. In these two complexes the intraligand $\pi-\pi^{*}$ state appears lowest in energy. The absorption spectra of $\mathrm{ClRe}(\mathrm{CO})_{3}$ (trans-4-styrylpyridine $)_{2}$ and $\mathrm{ClRe}(\mathrm{CO})_{3}$ (pyridine) ${ }_{2}$ are compared in Figure 2 and Table 4 and 


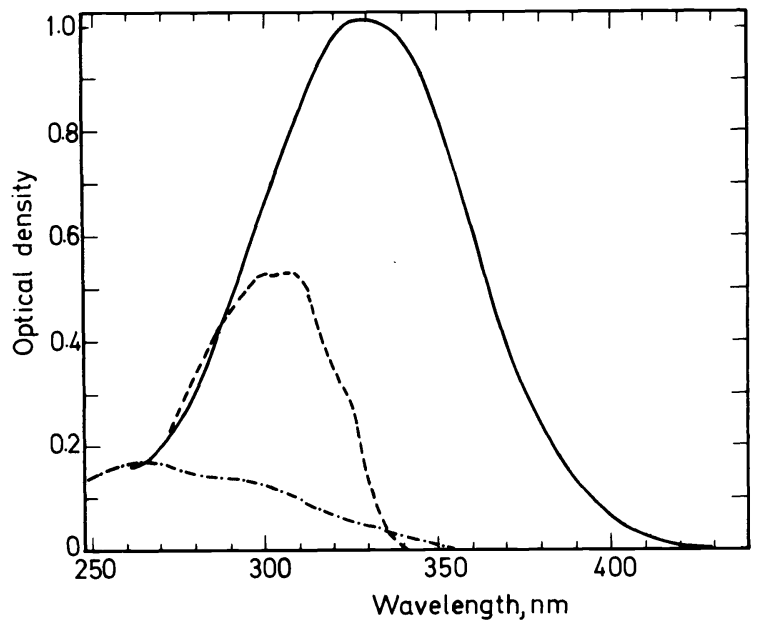

Figure 2. Comparison of absorption spectra of trans-4-styrylpyridine (---- $), \mathrm{ClRe}(\mathrm{CO})_{3}$ $(t-4 \text {-styrylpyridine })_{2}(-)$, and $\mathrm{ClRe}(\mathrm{CO})_{3}$ (pyridine $)_{2}(-\cdot-\cdot)$ all at $1.92 \times 10^{-5} \mathrm{M}^{-}$in $\mathrm{CH}_{2} \mathrm{Cl}_{2}$ solution at $25^{\circ} \mathrm{C}$ in $1.00 \mathrm{~cm}$ pathlength cells.

i.r. data are included in Table 2. Photolysis at $436 \mathrm{~nm}$ of the $\mathrm{ClRe}(\mathrm{CO})_{3^{-}}$(trans-4-styrylpyridine) ${ }_{2}$ and the corresponding bromo complex yield very efficient trans-cis isomerization of the ligand $\left(\Phi_{t \rightarrow c} 0.5\right)$ and ultimately essentially all of the 4-styrylpyridine is isomerized to the cis isomer. However, photosubstitution of the cis-4-styrylpyridine is not efficient and $\mathrm{ClRe}(\mathrm{CO})_{5}$ is not a good photoassistance agent for the trans-cis isomerization of 4-styrylpyridine even though photolysis of $\mathrm{ClRe}(\mathrm{CO})_{5}$ yields the bis-4styrylpyridine complexes with a quantum yield of $\sim 0.10$ at $366 \mathrm{~nm}$.

The results cited here for the $\mathrm{XRe}(\mathrm{CO})_{3}$ (trans-4-styrylpyridine $)_{2}$ are the first which allow some comment to be made concerning the perturbation by coordination of the excited state chemistry of the ligand since the intraligand excited state is the lowest excited state of the complex. We see here some evidence for a perturbation of the chemistry by noting that the tendency for the coordinated ligand to undergo cis $\rightarrow$ trans photoisomerization is very small. But neither the electronic spectra nor the trans $\rightarrow$ cis photoisomerization data suggest a large change in the excited state properties of the coordinated trans-4-styrylpyridine. The $\sim 0.5$ quantum yield is, however, experimentally distinguishable from the 0.37 for the free ligand ${ }^{9}$.

\section{(b) Photoassistance and photocatalysis by generation of coordinative unsaturation}

We have undertaken a general study of the activation of olefins upon photogeneration of coordinative unsaturation in metal carbonyls. Coordinatively unsaturated metal carbonyls can lead to net simple substitution chemistry as shown in equations (8) and (9) or to net oxidative addition chemistry $^{10}$ as shown in equations (12) and (13) ${ }^{11}$. For the example shown the oxidative addition results in a formal change of the iron from 0 to +2 oxidation state and corresponds to $\mathrm{ad}^{8} \rightarrow \mathrm{d}^{6}$ electronic configuration change. 
MARK S. WRIGHTON, D. S. GINLEY, M. A. SCHROEDER AND D. L. MORSE

The results in this section show how photoinduced oxidative additions and substitutions can be combined to achieve metal carbonyl photoassisted and photocatalysed reactions of olefins.

$$
\begin{gathered}
\mathrm{Fe}(\mathrm{CO})_{5} \stackrel{h v}{\longrightarrow} \mathrm{Fe}(\mathrm{CO})_{4}+\mathrm{CO} \\
\mathrm{Fe}(\mathrm{CO})_{4}+\mathrm{Ph}_{3} \mathrm{Si}-\mathrm{H} \rightarrow c i s-\mathrm{HFe}(\mathrm{CO})_{4} \mathrm{SiPh}_{3}
\end{gathered}
$$

(1) $\mathrm{M}(\mathrm{CO})_{6}(\mathrm{M}=\mathrm{Cr}, \mathrm{Mo}, \mathrm{W})$ Photoassisted and photocatalysed isomerization of olefins ${ }^{12}$

Near u.v.-photolysis of $\mathrm{M}(\mathrm{CO})_{6}(\mathrm{M}=\mathrm{Mo}, \mathrm{W}$ but curiously not $\mathrm{Cr})$ in the presence of an olefin generally leads to isomerization of the olefin. Both cis-trans and positional isomerization have been detected as indicated by the examples in Table 5. All of the data are wholly consistent with the first photoreaction being the formation of the $\mathrm{M}(\mathrm{CO})_{5}($ olefin) complex with

Table 5. $\mathrm{M}(\mathrm{CO})_{6}$ photoassisted olefin isomerizations $\mathrm{s}^{\mathrm{a}}$

Irrdn $\lambda, \mathrm{nm}$

- From ref. 12. 
retention of the integrity of the olefin. At the very least, absorption of light by the $\mathrm{M}(\mathrm{CO})_{5}($ olefin) is required to achieve any olefin isomerization. Consider 1,3-hydrogen shift reactions leading to positional isomerization in the alkenes. As a specific example, the interconversion of the linear pentenes using $\mathrm{W}(\mathrm{CO})_{6}$ will be outlined. We begin with cis-2-pentene. Photogeneration of $\mathrm{W}(\mathrm{CO})_{5}($ cis-2-pentene) is achieved, as in equations (8) and (14). However, though olefin-olefin exchange does occur thermally no isomerized olefin appears in the medium and the i.r. spectra of W(CO) $)_{5}$-1-pentene, -cis-2- and -trans-2-pentene are all different, ruling out equilibration upon coordination.

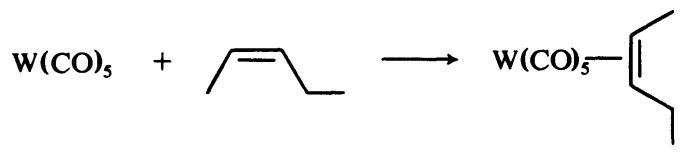

Absorption of light by the $\mathrm{W}(\mathrm{CO})_{5}($ cis-2-pentene) does take place and can lead directly to a species which catalytically interconverts the pentenes by photodissociation of $\mathrm{CO}$, equation (15). The quantum yield for $\mathrm{CO}$ release

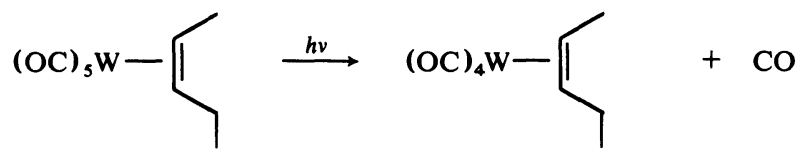

from $\mathrm{W}(\mathrm{CO})_{5}(1-$ pentene) at 366 or $313 \mathrm{~nm}$ is near 0.3 making this a fairly efficient photoprocess. Photodissociation of the alkene does take place, equation (16), but in the presence of the cis-2-pentene leads to no new

$$
(\mathrm{OC})_{s} \mathrm{~W}-\overbrace{\Delta}^{\stackrel{h v}{\rightleftarrows}}(\mathrm{OC})_{5} \mathrm{~W}+\longdiv { }
$$

products since the $\mathrm{W}(\mathrm{CO})_{5}$ is re-captured. The $(\mathrm{CO})_{4} \mathrm{~W}($ cis-2-pentene), though, leads to two possible types of products, equations (17) and (18). The thermal substitutional lability of the $\mathrm{W}(\mathrm{CO})_{4}(\text { cis-2-pentene })_{2}$ coupled with<smiles>C=CC/C=C(/C)NC(=O)[O-]</smiles>

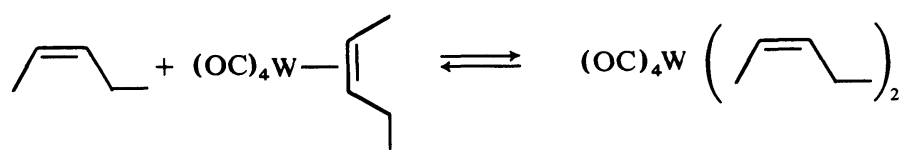


the possibility indicated in (17) may allow for catalytic isomerization. The oxidative addition of the alkene to $\mathrm{W}(\mathrm{CO})_{4}$ is more reasonable than to $\mathrm{W}(\mathrm{CO})_{5}$ since for $\mathrm{W}(\mathrm{CO})_{4}$ there is a smaller number of ligands available to stabilize the low valent metal. The oxidative addition can be viewed as resulting in a $\mathrm{d}^{6} \rightarrow \mathrm{d}^{4}$ change in electronic configuration of tungsten, and formation of the seven-coordinate intermediate satisfies the 18 electron rule. The isomerization of cis-2-pentene to 1-pentene may also occur, equation (19), from $\mathrm{W}(\mathrm{CO})_{4}$ (cis-2-pentene) and it in turn may yield trans-2-pentene. Note: (i) in these cases we have shown that cis-trans isomerization can proceed by

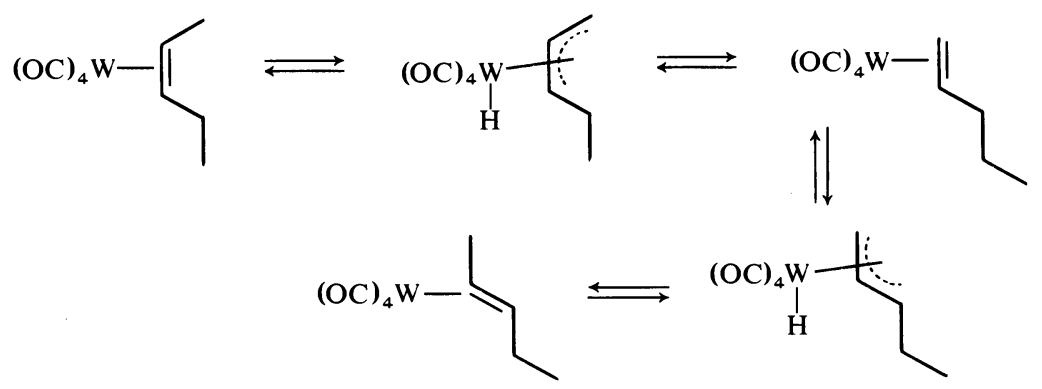

1,3-hydrogen shifts, (ii) we have inferred that the $\pi$-allyl system has some stereochemical integrity, and (iii) the scheme of equations (15-19) accounts for the observation that after a period of photolysis the isomerization of 1-pentene proceeds in the dark at $25^{\circ}$, Table 6. However, the number of COs

Table 6. Photolysis and thermolysis of $\mathrm{W}(\mathrm{CO})_{6}-1$-pentene solutions ${ }^{\mathrm{a}}$

\begin{tabular}{cccccc}
\hline $\begin{array}{c}\text { Irrdn time, } \\
\text { min }\end{array}$ & $\begin{array}{c}\text { Time thermolysed } \\
\text { after photolysis, min }\end{array}$ & $\begin{array}{c}1-\text { pentene } \\
\%\end{array}$ & $\begin{array}{c}\text { trans-2 } \\
\%\end{array}$ & $\begin{array}{c}\text { cis-2 } \\
\%\end{array}$ & $(t / c)$ \\
\hline 1350 & 0 & 96.27 & 3.22 & 0.50 & 6.44 \\
1350 & 1388 & 94.67 & 4.42 & 0.91 & 4.90 \\
2744 & 0 & 83.74 & 14.11 & 2.14 & 6.64 \\
4226 & 0 & 68.85 & 27.37 & 3.78 & 7.31 \\
4233 & 3503 & 61.82 & 31.35 & 6.83 & 4.59 \\
7054 & 0 & 43.55 & 48.95 & 7.60 & 6.40 \\
\hline
\end{tabular}

${ }^{a}$ Irradiation carried out in a $366 \mathrm{~nm}$ merry-go-round with $\sim 10^{-3} \mathrm{M} \mathrm{W}(\mathrm{CO})_{6}, 5 \times 10^{-2} \mathrm{M} 1$-pentene in isooctane at $30^{\circ} \mathrm{C}$. Thermolysis was done under the same conditions except that the samples were protected from the light for the times indicated. Data are from ref. 12.

remaining on the tungsten is clearly not proven, and there is some evidence that a $\mathrm{W}(\mathrm{CO})_{3}$ unit may be involved as the ultimate catalytic species. It is likely, though, that the mechanism given in (15-19) accounts in large part for the photocatalysis. Consistent with true photocatalysis we find that (i) the linear pentenes are ultimately equilibrated to their thermodynamic ratio, and (ii) the reaction does proceed in the dark once the catalyst has been generated. We find, also, that photoaccelerated catalysis is possible in this instance. 
Two of the olefins (stilbene, 1,2-dideuterioethylene) in Table 5 have no allylic hydrogens and yet still undergo cis-trans isomerization. Obviously, the $\pi$-allyl hydride intermediate cannot be invoked here, and for the stilbenes we point to the fact that isomerization proceeds in the trans $\rightarrow$ cis direction. This represents movement away from the thermodynamic ratio and implicates electronically excited states as key intermediates. Equation (20) depicts a proposed pathway of olefin isomerization which features decay of an electronically excited state to a species having a $\mathrm{W}-\mathrm{C}$ sigma bond with free rotation about the $\mathrm{C}-\mathrm{C}$ bond formerly of double bond character. Such

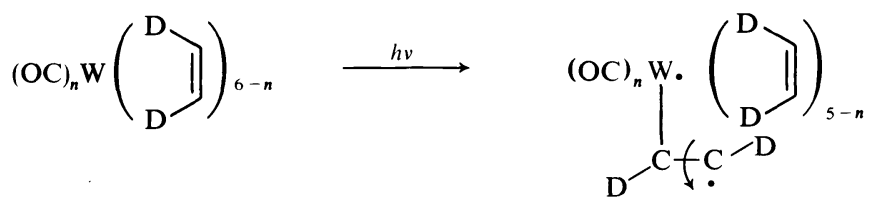

chemistry may also account for photoacceleration of thermal catalysis but if such a path is important in alkenes, then one may expect to alter the thermodynamic ratio of a set of alkene isomers as we find for the stilbenes. Isomerization of the stilbenes and the 1,3-dienes by an electronic energy migration mechanism producing a low lying intraligand triplet state cannot be ruled out, but the production of uncomplexed olefins in excited states is not observed.

The lack of isomerization activity by $\mathrm{Cr}(\mathrm{CO})_{6}$ is found for all reactions: 1,3-hydrogen shifts in 1-pentene, cis-trans isomerization of 1,3-dienes, and cis-trans isomerization of stilbenes. The reason for the lack of isomerization activity is not obvious, but this fact is serendipitous as will be recognized below.

(2) $\mathrm{M}(\mathrm{CO})_{6}(\mathrm{M}=\mathrm{Cr}, \mathrm{Mo}, \mathrm{W})$ Photoassisted and photocatalysed 1,4-addition of hydrogen to 1,3-dienes ${ }^{13}, 14$

The photolysis of $\mathrm{M}(\mathrm{CO})_{6}$ at $25^{\circ}$ in the presence of a 1,3-diene and hydrogen at $1 \mathrm{~atm}$ leads to 1,4-addition of hydrogen to the diene. Some starting materials and reaction products are given in Table 7. Importantly, $\mathrm{Cr}(\mathrm{CO})_{6}$ seems to work very effectively even though it is ineffective in olefin isomerization (vide supra). The hydrogenation of the 1,3-diene apparently requires the s-cis conformation of the 1,3-diene as proved by the data given in Table 8 . This seems to be true even for $\mathrm{W}(\mathrm{CO})_{6}$ and $\mathrm{Mo}(\mathrm{CO})_{6}$ but in these cases isomerization of the products does occur.

The data in Table 9 prove that the reaction is truly photocatalytic with the same reaction product appearing in the dark thermal reaction as in the continuous photolysis experiments. The high chemical yields and quantum efficiencies, the specificity of the hydrogenation, and the similarity of the chemistry obtained at $\sim 200^{\circ}$ and $500 \mathrm{lb} / \mathrm{in}^{2}$ hydrogen using (arene) $\mathrm{Cr}(\mathrm{CO})_{3}{ }^{15}$ as a hydrogenation catalyst has prompted us to explore in some detail the nature of the photogenerated catalyst. In particular, we have sought to establish whether $\mathrm{M}(\mathrm{CO})_{3}$ is the repeating catalytic species as proposed in the high temperature, high hydrogen pressure catalysis. 
MARK S. WRIGHTON, D. S. GINLEY, M. A. SCHROEDER AND D. L. MORSE

Table 7. $\mathrm{Cr}(\mathrm{CO})_{6}$ photocatalysed 1,4-addition of hydrogen to 1,3-dienes ${ }^{\mathrm{a}}$

Starting diene

- Near u.v. $(300-380 \mathrm{~nm})$ photolysis of $\mathrm{Cr}(\mathrm{CO})_{6}\left(\sim 10^{-3} \mathrm{M}\right)$ in degassed benzene solutions of the diene $\left(\sim 10^{-1} \mathrm{M}\right)$ at $25^{\circ} \mathrm{C}$ exposed to $1 \mathrm{~atm}$ hydrogen; refs 13,14 .

Table 8. Selective hydrogenation of s-cis-1,3-dienes by $\mathrm{M}(\mathrm{CO})_{6}$ photocatalysis $^{\mathrm{a}}$

Starting diene mixture

- Degassed benzene solutions of two dienes each at $\sim 0.05 \mathrm{M}$ and $\mathrm{M}(\mathrm{CO})_{6}\left(\sim 10^{-3} \mathrm{M}\right)$ and exposed to 1 atm hydrogen photolysed with near-u.v. $(300-380 \mathrm{~nm})$ light at $25^{\circ} \mathrm{C}$; ref. 13.

b This diene is recovered unreacted.

Table 9. $\mathrm{Cr}(\mathrm{CO})_{6}$ photocatalysed hydrogenation of 2-methyl-1,3-butadiene ${ }^{\mathrm{a}}$

\begin{tabular}{ccc}
\hline $\begin{array}{c}\text { Time irradiated } \\
\text { at } 10^{\circ} \mathrm{C}, \mathrm{h}\end{array}$ & $\begin{array}{c}\text { Time thermolysed } \\
\text { at } 25^{\circ} \mathrm{C}, \mathrm{h}\end{array}$ & $\%$ Hydrogenation \\
\hline 1 & 0 & 6.5 \\
1 & 18 & 14.3 \\
1 & 0 & 6.0 \\
1 & 15 & 14.9 \\
\hline
\end{tabular}

- $\mathrm{Cr}(\mathrm{CO})_{6}$ initially $2 \times 10^{-3} \mathrm{M}$, diene initially $10^{-1} \mathrm{M}$, and hydrogen at $1 \mathrm{~atm}$. The hydrogenation product from continuous photolysis and dark thermolysis is 2-methyl-2-butene; ref. 13. 
The complex (mesitylene) $\mathrm{Cr}(\mathrm{CO})_{3}$ serves as a catalyst for the 1,4-addition of hydrogen to 1,3-dienes at high temperatures and pressures ${ }^{15}$. Though arene group exchange is a thermal process ${ }^{16}$, equation (21), it is found that photoexcitation of (mesitylene) $\mathrm{Cr}(\mathrm{CO})_{3}$ only yields dissociation of $\mathrm{CO}^{17}$. equation (22), leading only to substitution, equation (23), and oxidative addition reaction, equation $(24)^{10}$. We find that even prolonged photolysis

$$
\begin{gathered}
\text { (mesitylene }) \mathrm{Cr}(\mathrm{CO})_{3} \stackrel{\Delta,>100^{\circ}}{\text { arene }}(\text { arene }) \mathrm{Cr}(\mathrm{CO})_{3}+\text { mesitylene } \\
\text { (mesitylene } \left.) \mathrm{Cr}(\mathrm{CO})_{3} \stackrel{h v}{25^{\circ}} \text { (mesitylene }\right) \mathrm{Cr}(\mathrm{CO})_{2}+\mathrm{CO} \\
\left.(\text { mesitylene }) \mathrm{Cr}(\mathrm{CO})_{2}+\text { olefin } \rightarrow(\text { mesitylene }) \mathrm{Cr}(\mathrm{CO})_{2} \text { (olefin }\right) \\
(\text { mesitylene }) \mathrm{Cr}(\mathrm{CO})_{2}+\mathrm{R}_{3} \mathrm{SiH} \rightarrow(\text { mesitylene }) \mathrm{Cr}(\mathrm{CO})_{2} \mathrm{HSiR}_{3}
\end{gathered}
$$

of (mesitylene) $\mathrm{Cr}(\mathrm{CO})_{3}$ in the presence of a 1,3-diene at $1 \mathrm{~atm}$ hydrogen yields no detectable hydrogenation, consistent with the necessity of losing the arene group. Our negative result also reinforces the fact that photochemistry and thermal chemistry can be markedly different in a potentially useful way.

The fact remains, though, that after a period of photolysis of $\mathrm{Cr}(\mathrm{CO})_{6}$ the 1,4-hydrogenation can proceed thermally under very mild conditions to give the same products as found using (arene) $\mathrm{Cr}(\mathrm{CO})_{3}$ at high temperatures and pressures. This information suggests that any $\mathrm{Cr}(\mathrm{CO})_{3} \mathrm{~L}_{3}$ complex, could serve as a 1,4-hydrogenation catalyst at moderate conditions if $\mathrm{L}$ is a weakly bound, thermally substitution labile, ligand. The $\left(\mathrm{CH}_{3} \mathrm{CN}\right)_{3} \mathrm{Cr}(\mathrm{CO})_{3}$ complex is known ${ }^{18}$ to be thermally labile at low temperatures with respect to loss of $\mathrm{CH}_{3} \mathrm{CN}$, and we have investigated its ability to serve as a catalyst for the 1,4-addition of hydrogen to 1,3-dienes. Typical results are given in Table $10^{19}$. As shown $\left(\mathrm{CH}_{3} \mathrm{CN}\right)_{3} \mathrm{Cr}(\mathrm{CO})_{3}$ operates as a catalyst with the same specificity as $\mathrm{Cr}(\mathrm{CO})_{6}$ photocatalysis at very mild conditions in comparison to (mesitylene) $\mathrm{Cr}(\mathrm{CO})_{3}$ and gives synthetic yields of the hydrogenated product. Thus, in a small way, our studies in photocatalysis have led to enough understanding of the thermal catalysis to run the reaction considerably more conveniently and moderately with respect to reaction conditions. Each reaction probably proceeds via a $\mathrm{Cr}(\mathrm{CO})_{3}$ repeating unit with the remainder of the coordination sphere filled with olefin and hydrogen which can oxidatively add in the $d^{6} \rightarrow d^{4}$ sense.

\section{(3) $\mathrm{Cr}(\mathrm{CO})_{6}$ Photocatalysed 1,4-hydrosilation of 1,3-dienes ${ }^{20}$}

The specificity of photocatalysed 1,4-addition of hydrogen to 1,3-dienes has prompted us to search for other substrates besides hydrogen which could be used to functionalize the olefin. We have been prompted to investigate silanes since silanes containing an $\mathrm{Si}-\mathrm{H}$ bond add oxidatively either $d^{8} \rightarrow d^{6}$ or $d^{6} \rightarrow d^{4}$ to photogenerated coordinatively unsaturated metal carbonyls as shown in equations (13) and (24), respectively ${ }^{10}$. We find that silanes containing an $\mathrm{Si}-\mathrm{H}$ bond do add to 1,3-dienes upon photolysis of $\mathrm{Cr}(\mathrm{CO})_{6}$ at $25^{\circ}$, Table 11 . We find quantitative generation of allylsilanes beginning with neat 1:1 mole ratios of the diene and the silane. It appears that 1,4-addition always obtains, cis-alkenes are generated, and the s-cis conformation of the diene is required. The similarity of the reactivity of 


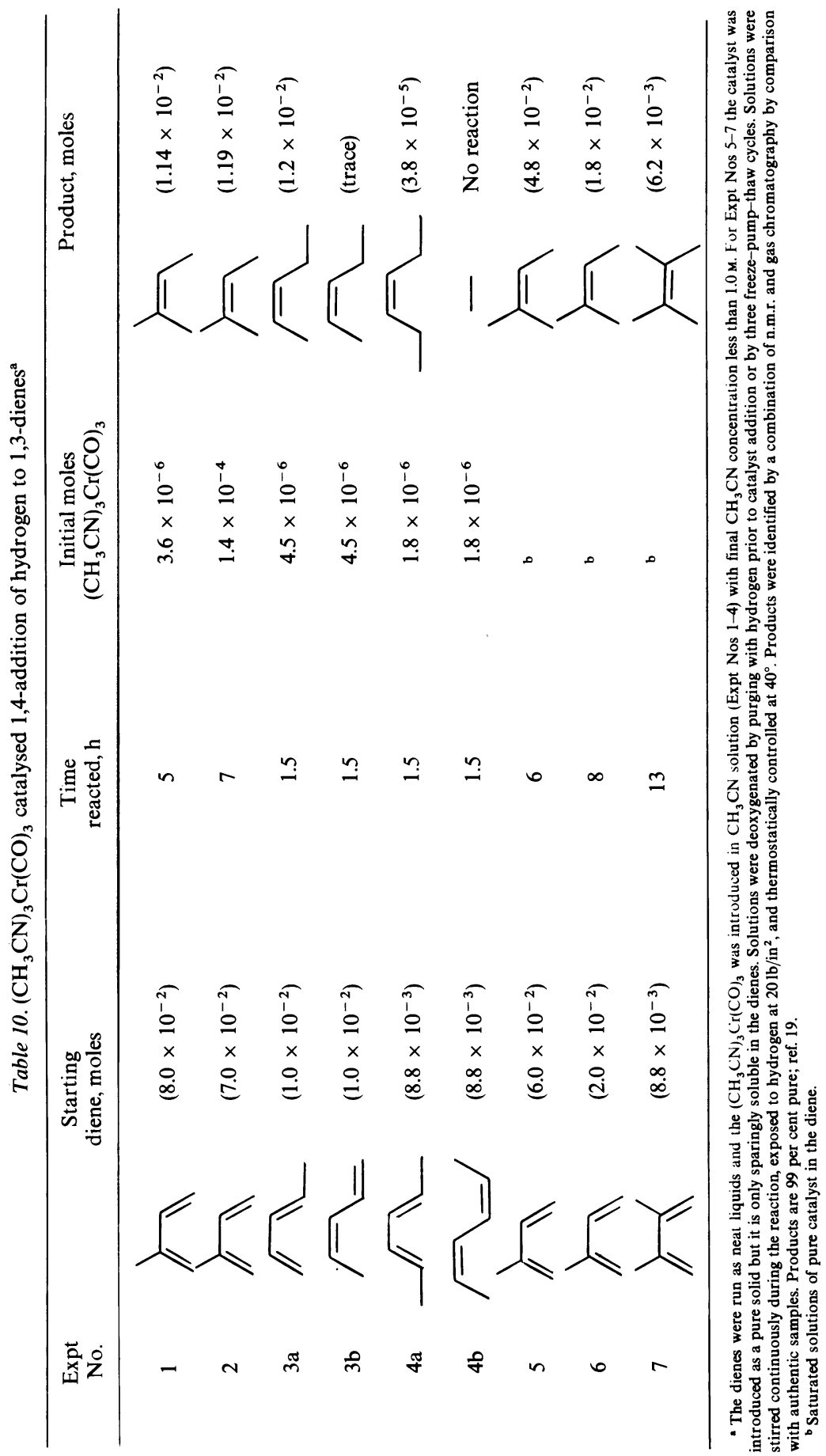


Table 11. Allylsilanes synthesized by $\mathrm{Cr}(\mathrm{CO})_{6}$ photocatalysed 1,4-hydrosilation of 1,3-dienes ${ }^{\mathrm{a}}$

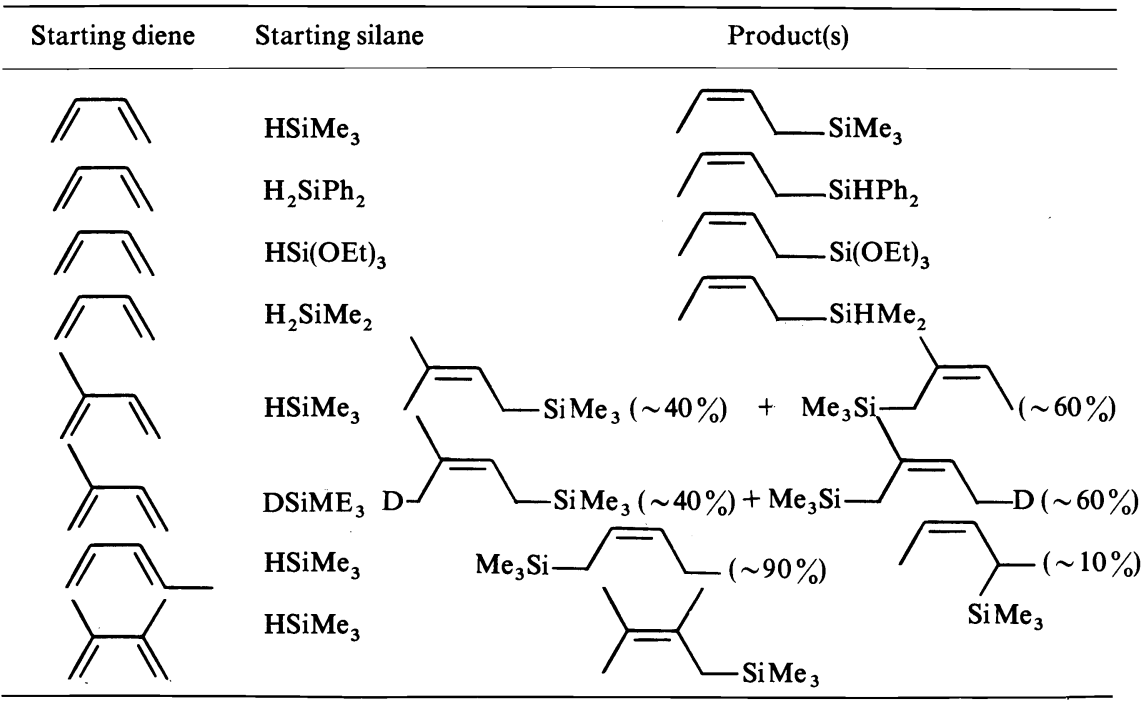

\footnotetext{
- These reactions are carried out on the neat substrates in approximately $1: 1$ mole ratios on an approximately 0.05 mole scale. The deoxygenated solutions are saturated in $\mathrm{Cr}(\mathrm{CO})_{6}$ and exposed for several days to the output of a black light equipped with two $15 \mathrm{~W}$ GE Black Light bulbs. The reaction temperature is approximately $30^{\circ} \mathrm{C}$. The products were generally identified by gas chromatography ( $\beta \beta^{\prime}$-ODPN or OV-101 column), n.m.r. and i.r. spectra after distillation to remove catalyst and residual starting materials; ref. 20.
}

hydrogen and the silanes is remarkable, but one major difference has emerged: 1,4-hydrogenation of dienes containing alkyl substituents in the 1 and 4 positions of the diene proceeds but 1,4-hydrosilation does not, and when there is an alkyl group in the 1 or 4 position of the diene the silyl group adds to the least sterically hindered position. The alkyl substituent effect is most certainly a steric effect as the electronic variation among the silanes that add is very large. The photocatalytic synthesis of allylsilanes has some advantage over the conventional synthetic procedures ${ }^{21}$ of (i) reaction of $\mathrm{NaSiR}_{3}$ with an allylhalide or (ii) reaction of allyl lithium with $\mathrm{XSiR}_{\mathbf{3}}(\mathrm{X}=$ halogen).

(4) $\mathrm{Fe}(\mathrm{CO})_{5}$ Photoassisted and photocatalysed olefin isomerization and hydrogenation

Like $\mathrm{M}(\mathrm{CO})_{6}(\mathrm{M}=\mathrm{Cr}, \mathrm{Mo}, \mathrm{W})$ photodissociation of $\mathrm{CO}$ from $\mathrm{Fe}(\mathrm{CO})_{5}$ occurs with high quantum efficiency and the $\mathrm{Fe}(\mathrm{CO})_{4}$ generated is susceptible to oxidative addition, equation (12), or may simply be captured by a twoelectron donor in the medium. We find that photolysis of $\mathrm{Fe}(\mathrm{CO})_{5}$ in the presence of an olefin and hydrogen $(1 \mathrm{~atm})$ at $25^{\circ}$ leads to hydrogenation of the olefin, Table 12. Alkenes are most readily hydrogenated, though 1,3-dienes and acetylenes also undergo some reduction. Thermal hydrogenation of olefins using $\mathrm{Fe}(\mathrm{CO})_{5}$ as a catalyst is known ${ }^{22}$, but the catalysis requires both high temperature and high hydrogen pressure. Thus, the photochemical route may again be a synthetically useful procedure. 
MARK S. WRIGHTON, D. S. GINLEY, M. A. SCHROEDER AND D. L. MORSE

Table 12. $\mathrm{Fe}(\mathrm{CO})_{5}$ photoassisted hydrogenation of olefins ${ }^{\mathrm{a}}$

\begin{tabular}{|c|c|c|}
\hline Starting olefin & Time irrdtd, min & Product ( $\%$ conversion) \\
\hline Cyclopentene & 60 & Cyclopentane (47.0) \\
\hline Cyclohexene & 60 & Cyclohexane (33.1) \\
\hline Cycloheptene $^{\mathrm{b}}$ & 60 & Cycloheptane (53.2) \\
\hline cis-Cyclooctene ${ }^{\mathrm{b}}$ & 60 & Cyclooctane (53.5) \\
\hline cis-3-Hexene & 60 & $n$-Hexane (30.8) \\
\hline 1-Methylcyclopentene & 60 & Methylcyclopentane (26.3) \\
\hline 2-Methyl-2-butene & 60 & 2-Methylbutane (26.9) \\
\hline 2,3-Dimethyl-2-butene & 60 & 2,3-Dimethylbutane (13.6) \\
\hline 1,2-Dimethylcyclopentene & 60 & No reaction \\
\hline 1,2-Dimethylcyclohexene & 60 & No reaction \\
\hline Diphenyl acetylene ${ }^{c}$ & 160 & $\begin{array}{l}\text { cis-Stilbene (5.0) } \\
\text { trans-Stilbene (3.5) }\end{array}$ \\
\hline Diethyl acetylene & 60 & Linear hexenes $(\sim 6.0)$ \\
\hline trans,trans-2,4-Hexadiene & 305 & $\begin{array}{l}\text { Linear hexenes (35.0) } \\
n \text {-Hexane }(5.2)\end{array}$ \\
\hline cis,cis-2,4-Hexadiene & 315 & $\begin{array}{l}\text { Linear hexenes }(30.0) \\
n \text {-Hexane }(4.7)\end{array}$ \\
\hline cis-1,3-Pentadiene & 300 & Pentenes (4) \\
\hline trans-1,3-Pentadiene & 400 & Pentenes (8.5) \\
\hline
\end{tabular}

- Irradiation with $450 \mathrm{~W}$ medium pressure mercury Hanovia lamp filtered with a Corning No. CS7-54 to pass $\sim 300-380 \mathrm{~nm}$ light $\sim 10^{-5}-10^{-6}$ ein $/ \mathrm{min} ; \mathrm{Fe}(\mathrm{CO})_{5}$ is initially $3 \times 10^{-3} \mathrm{M}$; temperature is $25^{\circ} \mathrm{C}$; solvent is benzene; olefin is $0.1 \mathrm{M}$, and hydrogen is at $10 \mathrm{lb} / \mathrm{in}^{2}$; unless noted otherwise.

${ }^{\mathrm{b}}$ Solvent is 2-methylbutane.

' Solvent is 2,2,4-trimethylpentane.

To gain some feel for catalyst selectivity we have investigated the relative rates of alkene hydrogenation as a function of alkene structure using the $\mathrm{Fe}(\mathrm{CO})_{5}$-light system. The data in Table 12 suggest only a modest variation in hydrogenation rate from terminal alkenes such as 1-pentene to the tetraalkyl alkene 2,3-dimethyl-2-butene. In competition experiments, however, we find some selectivity for hydrogenation of terminal alkenes as with the $\mathrm{d}^{8}$ $\mathrm{HRuCl}\left(\mathrm{PPh}_{3}\right)_{3}$ and $\mathrm{HRhCl}\left(\mathrm{PPh}_{3}\right)_{3}$ catalysts ${ }^{23}$. One remarkable result is that neither 1,2-dimethylcyclopentene nor 1,2-dimethylcyclohexene undergoes detectable hydrogenation. Neither of these is an inhibitor of the hydrogenation and both appear to be inert under the reaction conditions.

Accompanying the hydrogenation in the case of alkenes is rapid olefin isomerization ${ }^{24}$ as shown in Table 13. The degree of isomerization versus hydrogenation clearly depends on the olefin and in the case of cis-3-hexene-1ol the sequential 1,3-hydrogen shifts leading to hexanal apparently occur so fast that hydrogenation is not at all competitive.

The mechanism for both isomerization and hydrogenation of alkenes likely begins with the formation of $\mathrm{Fe}(\mathrm{CO})_{4}$ (alkene) by equations (12) and (25).

$$
\mathrm{Fe}(\mathrm{CO})_{4}+\text { alkene } \rightarrow \mathrm{Fe}(\mathrm{CO})_{4} \text { (alkene) }
$$

Complexes such as $\mathrm{Fe}(\mathrm{CO})_{4}\left(1\right.$-hexene) are essentially substitutionally inert ${ }^{25}$ at $25^{\circ}$ with respect to alkene or $\mathrm{CO}$ substitution and surprisingly, the $\mathrm{Fe}(\mathrm{CO})_{4}$ (alkene) is apparently quite robust under photolytic conditions. The $\mathrm{Fe}(\mathrm{CO})_{5}$ photoassisted equilibration of the linear pentenes in the absence of hydrogen beginning with any one of the three isomers yields the same ratio of alkenes, 
Table 13. Competitive $\mathrm{Fe}(\mathrm{CO})_{5}$ photoassisted intramolecular isomerization and hydrogenation of olefins ${ }^{\mathrm{a}}$

Starting olefin $\begin{gathered}\text { Time } \\ \text { irrdtd, min }\end{gathered}$

${ }^{\text {a }} \mathrm{Fe}(\mathrm{CO})_{5}$ at $3 \times 10^{-3} \mathrm{M}$; hydrogen at $10-14 \mathrm{lb} / \mathrm{in}^{2} ; 25^{\circ} \mathrm{C}, 300-380 \mathrm{~nm}$ photolysis at $\sim 10^{-5} \mathrm{ein} / \mathrm{min}$.

Table 14. $\mathrm{Fe}(\mathrm{CO})_{5}$ photoassisted equilibration of linear pentenes ${ }^{\mathrm{a}}$

Starting isomer

Composition at infinite photolysis time

\begin{tabular}{lccc} 
& $\% 1$-Pentene & $\%$ trans-2-Pentene & $\%$ cis-2-Pentene \\
\hline 1-Pentene & 3.0 & 76.0 & 21.0 \\
trans-2-Pentene & 3.3 & 75.7 & 21.0 \\
cis-2-Pentene $^{2}$ & 3.3 & 76.1 & 20.6 \\
\hline Thermally equilibrated $^{\mathrm{b}}$ & 3.3 & 76.5 & 20.2 \\
\hline
\end{tabular}

- $\mathrm{Fe}(\mathrm{CO})_{5}$ at $10^{-3} \mathrm{M}$, olefin at $10^{-1} \mathrm{M}$, at $18^{\circ} \mathrm{C}$.

b $\mathrm{PdCl}_{2}$ thermal catalysis, G. C. Bond and M. Hellier, J. Catal. 4, 1 (1965).

Table 14, and this ratio is very close to the thermodynamic ratio. Even at equilibration, though, the $\mathrm{Fe}(\mathrm{CO})_{4}$ (alkene) is still the only i.r. detectable iron carbonyl species present in solution and there is little evidence for a species such as $\mathrm{Fe}(\mathrm{CO})_{3}$ (alkene $)_{2}$ formed by irradiation of $\mathrm{Fe}(\mathrm{CO})_{4}$ (alkene), equation (26). Formation of a catalytic amount of $\mathrm{Fe}(\mathrm{CO})_{3}$ (alkene) $)_{2}$, how-

$$
\left.\mathrm{Fe}(\mathrm{CO})_{4}(\text { alkene }) \underset{\text { alkene }}{\stackrel{h v}{\longrightarrow}} \mathrm{Fe}(\mathrm{CO})_{3} \text { (alkene }\right)_{2}
$$

ever, provides a convenient isomerization mechanism as shown in equations (27)-(30) for 1-pentene isomerization to trans-2-pentene. Such a sequence

$$
(\mathrm{OC})_{3} \mathrm{Fe}(1 \text {-pentene })_{2} \stackrel{\Delta}{\rightleftarrows}(\mathrm{OC})_{3} \mathrm{Fe}(1 \text {-pentene })+1 \text {-pentene }
$$

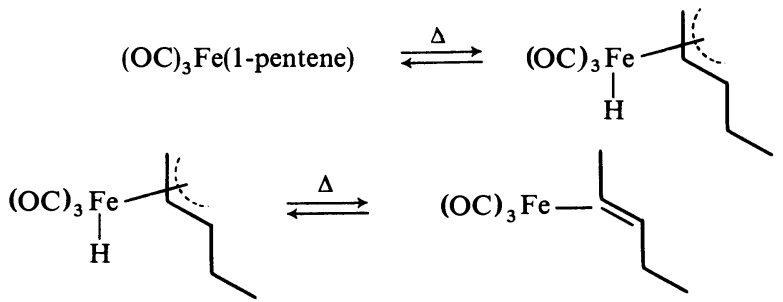


MARK S. WRIGHTON, D. S. GINLEY, M. A. SCHROEDER AND D. L. MORSE

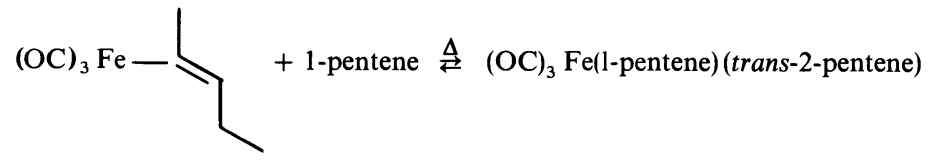

would account for the thermodynamic ratio of alkenes ultimately found. The lack of any substantial $\mathrm{Fe}(\mathrm{CO})_{3}$ (alkene) ${ }_{2}$ buildup may be due to a reaction such as (31) since we begin with $\mathrm{Fe}(\mathrm{CO})_{5}$ and are working in a closed system.

$$
\mathrm{Fe}(\mathrm{CO})_{3}(\text { alkene })_{2} \stackrel{\mathrm{CO}}{\rightarrow} \mathrm{Fe}(\mathrm{CO})_{4} \text { (alkene) }
$$

In the presence of hydrogen the known $\mathrm{H}_{2} \mathrm{Fe}(\mathrm{CO})_{4}$ could be generated and can lead to hydrogenation or isomerization ${ }^{26}$, but we find that it is not the likely catalyst here. Preliminary results point to a mechanism involving $\mathrm{Fe}(\mathrm{CO})_{3}$ as the repeating unit, perhaps as indicated in equations (32)-(34).
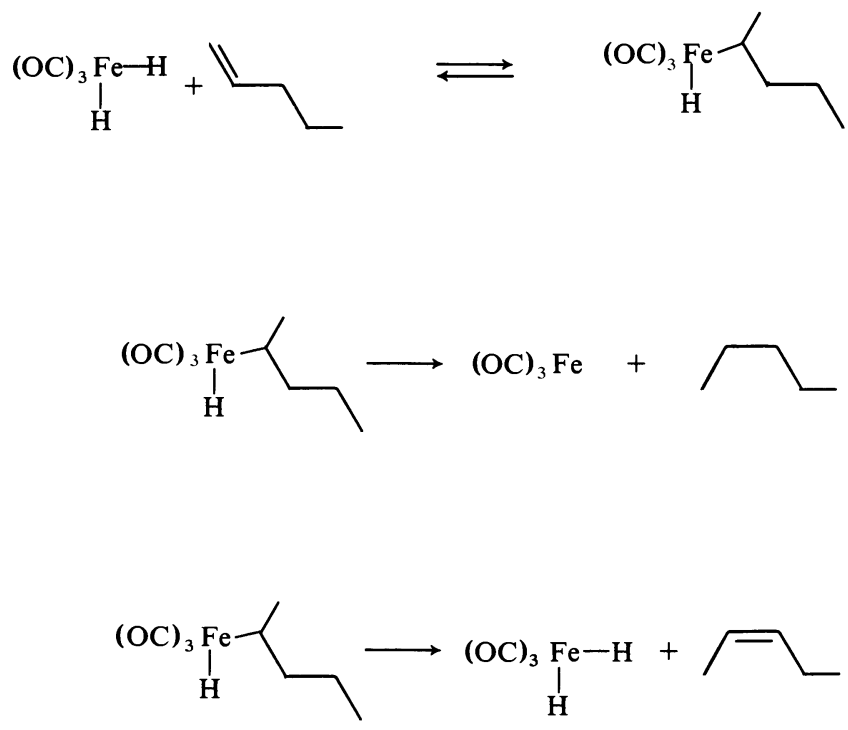

\section{(c) Photoinduced cleavage of direct metal-metal bonds}

Direct metal-metal bonds are an important structural unit in polynuclear metal carbonyls ${ }^{27}$, but little effort has been directed towards reactions which could lead to declusterification of such complexes by cleavage of the metalmetal bonds. The homolytic cleavage of a metal-metal bond should lead to paramagnetic organometallic complexes possessing exceptional properties 
with respect to electronic structure and reactivity. Indeed, there seems to be only one stable, paramagnetic, metal carbonyl: $\mathrm{V}(\mathrm{CO})_{6}$. We have initiated a systematic study of the photoreactivity of metal-metal bonded carbonyls especially with the aim of cleaving the metal-metal bond. Intermediates thus generated may be catalysts for olefin activation. For example, consider the $\mathrm{d}^{7}$, $C_{4 \mathrm{y}}, \mathrm{Co}(\mathrm{CN})_{5}^{3-}$ complex which exists as a dimer in the solid state with a $\mathrm{Co}-\mathrm{Co}$ bond ${ }^{28}$ and is overall structurally analogous to $\mathrm{Mn}_{2}(\mathrm{CO})_{10}$. The $\mathrm{Co}(\mathrm{CN})_{5}^{3-}$ in solution reacts with olefins, alkyl halides ${ }^{29}$, sulphur dioxide ${ }^{30}$, oxygen $^{31}$, and serves as a homogeneous hydrogenation catalyst for 1,3dienes at $25^{\circ}$. Homolytic cleavage of the $\mathrm{Mn}-\mathrm{Mn}$ bond in $\mathrm{Mn}_{2}(\mathrm{CO})_{10}$ would generate an $\mathrm{Mn}(\mathrm{CO})_{5}$ intermediate of $\mathrm{d}^{7}$ electronic configuration which may have some reactivity properties in common with $\mathrm{Co}(\mathrm{CN})_{5}^{3-}$. The fact that $\mathrm{Mn}_{2}(\mathrm{CO})_{10}$ is only found as a dimer though suggests that the $\mathrm{Mn}(\mathrm{CO})_{5}$ species may be even more reactive than the isoelectronic $\mathrm{Co}(\mathrm{CN})_{5}^{3-}$ species.

We have completed some initial studies designed to investigate the efficiency of metal-metal bond cleavage as a primary photoreaction in the compounds I-VI below.

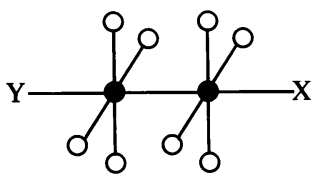

\begin{tabular}{|c|c|c|c|c|c|}
\hline $\begin{array}{l}O=\mathrm{Re} \\
\mathrm{O}=\mathrm{CO} \\
\mathrm{X}=\mathrm{CO} \\
\mathrm{Y}=\mathrm{CO}\end{array}$ & II & $\begin{array}{l}\mathrm{O}=\mathrm{Mn} \\
\mathrm{O}=\mathrm{CO} \\
\mathrm{X}=\mathrm{CO} \\
\mathrm{Y}=\mathrm{CO}\end{array}$ & III & $\begin{array}{l}\quad=\mathrm{Mn} \\
\mathrm{O}=\mathrm{CO} \\
\mathrm{X}=\mathrm{PPh}_{3} \\
\mathrm{Y}=\mathrm{CO}\end{array}$ & IV \\
\hline
\end{tabular}

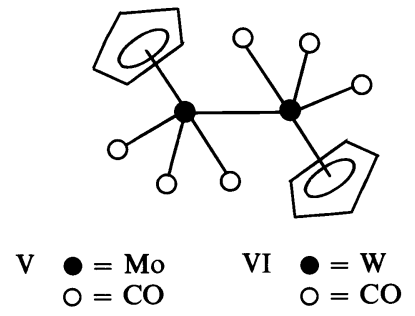

Consider first the $\mathrm{Mn}$ and $\mathrm{Re}$ complexes. Their lowest electronically excited states feature one-electron population of an orbital which is strongly $\sigma$-antibonding with respect to the metal-metal bond. The absorptions corresponding to $\sigma_{\mathrm{b}} \rightarrow \sigma^{*}$ and $\pi-\mathrm{d} \rightarrow \sigma^{* 33}$, Scheme III, and especially $\sigma_{\mathrm{b}} \rightarrow \sigma^{*}$, dominate the near-u.v. spectral region, Figure 3. Photolysis of I-IV in pure, degassed $\mathrm{CCl}_{4}$ proceeds essentially as indicated in equation $(35)^{34,35}$. Quantum yields are summarized in Table 15 . The data show that metal-metal bond cleavage is an efficient photoreaction and leads to high 
MARK S. WRIGHTON, D. S. GINLEY, M. A. SCHROEDER AND D. L. MORSE

$\mathrm{Y}(\mathrm{OC})_{4} \mathrm{M} \quad \mathrm{Y}(\mathrm{OC})_{4} \mathrm{M}-\mathrm{M}(\mathrm{CO})_{4} \mathrm{X} \quad \square \mathrm{M}(\mathrm{CO})_{4} \mathrm{X}$

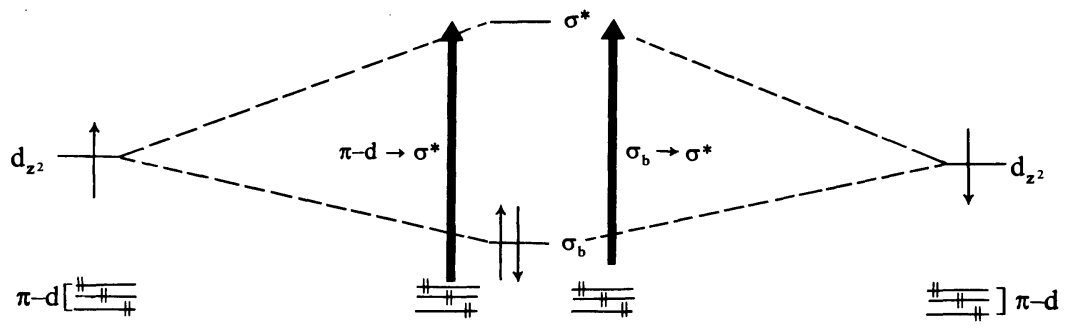

Scheme III

Table 15. Quantum yields for reaction of metal-metal bonded compounds in $\mathrm{CCl}_{4}^{\mathrm{a}}$

\begin{tabular}{cccccc}
\hline $\begin{array}{c}\text { Starting } \\
\text { material }\end{array}$ & Product & $\begin{array}{c}\text { Irradiation } \\
\lambda, \mathrm{nm}\end{array}$ & $\Phi_{\text {dis. }} \pm 10 \%$ & $\Phi_{\text {form }} \pm 10 \%$ & $\frac{\Phi_{\text {formn }}}{\Phi_{\text {dis. }}}$ \\
\hline II & $\mathrm{Mn}(\mathrm{CO})_{5} \mathrm{Cl}$ & 366 & 0.41 & 0.72 & 1.76 \\
& $\mathrm{Mn}(\mathrm{CO})_{5} \mathrm{Cl}$ & 313 & 0.48 & 1.02 & 2.13 \\
III & $\mathrm{Mn}(\mathrm{COO})_{5} \mathrm{Cl}$ & 366 & 0.45 & 0.36 & 0.80 \\
& $\mathrm{Ph}_{3} \mathrm{PMn}(\mathrm{CO})_{4} \mathrm{Cl}$ & 366 & 0.70 & 0.40 & 0.89 \\
IV & $\mathrm{Ph}_{3} \mathrm{PMn}(\mathrm{CO})_{4} \mathrm{Cl}$ & $\mathrm{Cl}$ & & 0.48 & 0.69 \\
I & $\mathrm{Re}(\mathrm{CO})_{5} \mathrm{Cl}$ & 313 & 0.60 & 1.20 & $2.0 \pm 0.1$ \\
\hline
\end{tabular}

Ref. 34, 35 .

$$
\mathrm{X}(\mathrm{OC})_{4} \mathrm{M}-\mathrm{M}(\mathrm{CO})_{4} \mathrm{Y} \underset{\mathrm{CCl}_{4}}{\stackrel{h v}{\rightarrow}} \mathrm{X}(\mathrm{OC})_{4} \mathrm{M}-\mathrm{Cl}+\mathrm{Y}(\mathrm{OC})_{4} \mathrm{M}-\mathrm{Cl}
$$

yields of the mononuclear species having an $\mathrm{M}-\mathrm{Cl}$ bond. Presumably, the $\mathrm{M}-\mathrm{Cl}$ arises from reaction of a photogenerated metal radical with $\mathrm{CCl}_{4}$. This is supported by photolysis of I-IV in benzene solutions of $\mathrm{Ph}_{3} \mathrm{CCl}$ which yields the mononuclear metal carbonyl chloride and the e.s.r. detectable $\mathrm{Ph}_{3} \mathrm{C}$ radical. Further, irradiation of $\mathrm{Re}_{2}(\mathrm{CO})_{10}$ in the presence of benzyl chloride leads to $\sim 70$ per cent yield of bibenzyl. Photolysis of either I or II in degassed isooctane solutions of iodine at low concentrations leads to disappearance of the metal-metal bonded compound and the iodine in a 1:1 ratio $^{35}$. The i.r. spectra data support the assignment of the product as $\mathrm{M}(\mathrm{CO})_{5} \mathrm{I}$. Reaction (36), then, is also consistent with the photogeneration of

$$
\mathrm{M}_{2}(\mathrm{CO})_{10}+\mathrm{I}_{2} \stackrel{366 \mathrm{~nm}}{\longrightarrow} 2 \mathrm{M}(\mathrm{CO})_{5} \mathrm{I}
$$

metal radicals and importantly, the disappearance quantum yields are very comparable to those in pure $\mathrm{CCl}_{4}$. The u.v. spectral changes accompanying reaction (36) for I are the same as those obtained for the photolysis of complex $\mathrm{I}$ in the presence of $\mathrm{CH}_{3} \mathrm{I}$. This result rules out the possibility that $\operatorname{Re}(\mathrm{CO})_{5}^{\ominus}$ is produced from I since this species is known ${ }^{3}$ to react with $\mathrm{CH}_{3} \mathrm{I}$ to give $\operatorname{Re}(\mathrm{CO})_{5} \mathrm{CH}_{3}$ and not $\operatorname{Re}(\mathrm{CO})_{5} \mathrm{I}$ as we find. The results reported here are in agreement with earlier qualitative studies ${ }^{36}$ of the photolysis of metal-metal bonded $\mathrm{Mn}$ and $\mathrm{Re}$ carbonyl complexes in the presence of a halogen donor. 


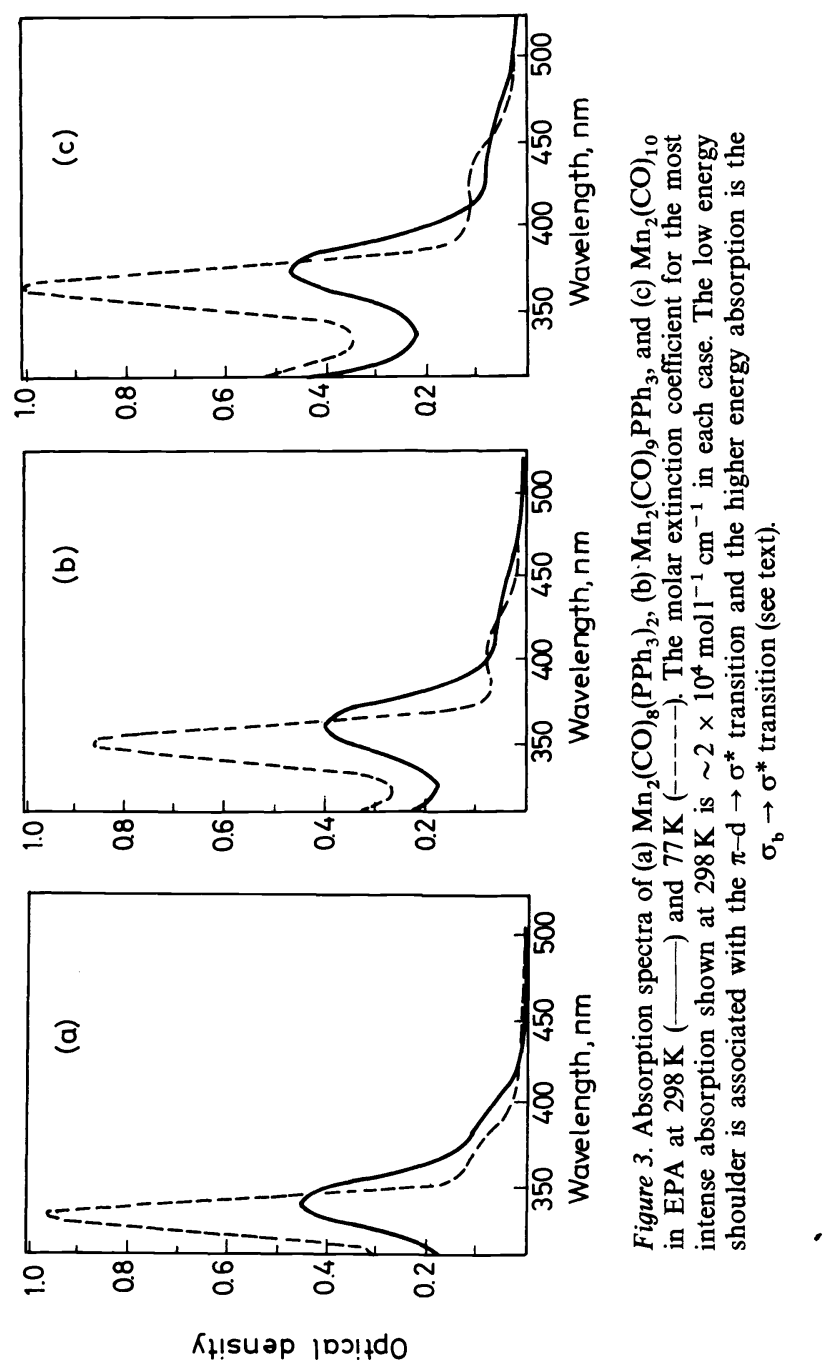


MARK S. WRIGHTON, D. S. GINLEY, M. A. SCHROEDER AND D. L. MORSE

Table 16. Flash photolysis of $\mathrm{Mn}_{2}(\mathrm{CO})_{9} \mathrm{PPh}_{3}$ in isooctane ${ }^{\mathrm{a}}$

\begin{tabular}{cccccc}
\hline \multicolumn{2}{c}{$\mathrm{Mn}_{2}(\mathrm{CO})_{9} \mathrm{PPh}_{3}$} & $\mathrm{Mn}_{2}(\mathrm{CO})_{10}$ & $\mathrm{Mn}_{2}(\mathrm{CO})_{8}\left(\mathrm{PPh}_{3}\right)_{2}$ & $\begin{array}{c}\% \\
\text { Yield }\end{array}$ \\
$\begin{array}{c}\text { No. of moles } \\
\text { initially present }\end{array}$ & $\begin{array}{c}\text { No. of moles } \\
\text { reacted }\end{array}$ & No. of moles formed & & $\frac{\mathrm{Mn}_{2}(\mathrm{CO})_{8}\left(\mathrm{PPh}_{3}\right)_{2}}{\mathrm{Mn}_{2}(\mathrm{CO})_{10}}$ \\
& & & & & \\
\hline $3.84 \times 10^{-6}$ & $5.76 \times 10^{-7}$ & $9.05 \times 10^{-8}$ & $9.30 \times 10^{-8}$ & 31 & 1.03 \\
$3.84 \times 10^{-6}$ & $1.06 \times 10^{-6}$ & $1.53 \times 10^{-7}$ & $1.20 \times 10^{-7}$ & 26 & 0.78 \\
$3.84 \times 10^{-6}$ & $1.06 \times 10^{-6}$ & $1.00 \times 10^{-7}$ & $1.77 \times 10^{-7}$ & 26 & 1.77 \\
$3.84 \times 10^{-6}$ & $1.28 \times 10^{-7}$ & $1.00 \times 10^{-7}$ & $0.68 \times 10^{-7}$ & 13 & $\frac{0.68}{\mathrm{Av} 1.06_{5}}$ \\
\hline
\end{tabular}

- Degassed isooctane solutions of $\mathrm{Mn}_{2}(\mathrm{CO})_{9} \mathrm{PPh}_{3}$ flashed with one or two Sylvania Type B flash bulbs; ref. 35.

A final series of experiments provides compelling evidence supporting the photoinduced cleavage of the metal-metal bond in complexes I-IV even in the absence of halogen donors. Either flash photolysis or continuous $366 \mathrm{~nm}$ photolysis of III in degassed isooctane proceeds according to reaction (37).

$$
\mathrm{Mn}_{2}(\mathrm{CO})_{9} \mathrm{PPh}_{3} \stackrel{h v}{\rightarrow} \mathrm{Mn}_{2}(\mathrm{CO})_{10}+\mathrm{Mn}_{2}(\mathrm{CO})_{8}\left(\mathrm{PPh}_{3}\right)_{2}
$$

Some representative data are given in Table 16 for this reaction. The important facts are that the two products are formed in good (but not quantitative) chemical yields and that the products are formed in a 1:1 ratio. The crosscoupling of other photogenerated $\mathrm{Mn}$ and Re fragments has been reported ${ }^{37}$ and is consistent with reaction (37).

The chemistry indicated in reactions (35)-(37) is at first inconsistent with another known fact: photolysis of $\mathrm{Mn}_{2}(\mathrm{CO})_{10}$ in the presence of nucleophiles leads to fairly good chemical yields of $\mathrm{CO}$ substituted products ${ }^{\mathbf{3 8}}$. The quantitative chemical yields obtained in $\mathrm{CCl}_{4}$ indicate that $\mathrm{CO}$ substitution probably does not proceed via photodissociation of the $\mathrm{CO}$ to generate a coordinatively unsaturated intermediate such as $\mathrm{Mn}_{2}(\mathrm{CO})_{9}$. A species such as $\mathrm{Mn}_{2}(\mathrm{CO})_{9}$ would be expected to have some reactivity properties similar to those of $\mathrm{W}(\mathrm{CO})_{5}$ [photogenerated from $\mathrm{W}(\mathrm{CO})_{6}$ ] which is irreversibly decomposed in $\mathrm{CCl}_{4}$ solution. The lack of quantitative yields for reaction (37) is consistent with thermally coordinatively labile metal fragments, as in reaction (38). The loss of $\mathrm{CO}$ from $\mathrm{M}(\mathrm{CO})_{5}$ and the further

$$
\mathrm{Mn}_{2}(\mathrm{CO})_{10} \underset{\Delta}{\stackrel{h v}{\rightleftarrows}} \mathrm{M}(\mathrm{CO})_{5} \stackrel{\Delta}{\rightarrow} \mathrm{M}(\mathrm{CO})_{4}+\mathrm{CO}
$$

decomposition of $\mathrm{M}(\mathrm{CO})_{4}$ may be only competitive with recombination of $\mathrm{M}(\mathrm{CO})_{5}$ to regenerate metal-metal bonds. Combination of $\mathrm{M}(\mathrm{CO})_{5}$ and $\mathrm{M}(\mathrm{CO})_{4}$, reaction (39), is an indirect pathway to generate coordinative unsaturation from $\mathrm{M}_{2}(\mathrm{CO})_{10}$. In the presence of potential entering groups, $\mathrm{L}$, another possibility exists and is shown in equation (40). We now have more direct evidence that substitution of the mononuclear metal radical by L occurs 


$$
\mathrm{M}(\mathrm{CO})_{5}+\mathrm{M}(\mathrm{CO})_{4} \stackrel{\Delta}{\rightarrow} \mathrm{M}_{2}(\mathrm{CO})_{9}
$$

followed by recombination of the metal radicals possibly according to the sequence indicated in (40). We find that $366 \mathrm{~nm}$ photolysis of $\mathrm{Mn}_{2}(\mathrm{CO})_{10}$

$$
\begin{aligned}
& \mathrm{M}_{2}(\mathrm{CO})_{10} \underset{\Delta}{\stackrel{h v}{\rightleftarrows}} \mathrm{M}(\mathrm{CO})_{5} \stackrel{\mathrm{L}}{\rightleftarrows} \mathrm{M}(\mathrm{CO})_{5} \mathrm{~L} \\
& \downarrow \stackrel{\downarrow}{\rightleftarrows} \\
& \mathrm{M}_{2}(\mathrm{CO})_{8} \mathrm{~L}_{2} \leftarrow \mathrm{M}(\mathrm{CO})_{4} \mathrm{~L}+\mathrm{CO}
\end{aligned}
$$

in a degassed isooctane solution of $\mathrm{PPh}_{3}$ proceeds according to equation (41); i.e. the disubstituted product is a primary photoproduct and we find a quantum yield for formation very nearly equal to that for the disappearance

$$
\mathrm{Mn}_{2}(\mathrm{CO})_{10} \underset{\mathrm{PPh}_{3}}{\stackrel{366 \mathrm{~nm}}{\longrightarrow}} \mathrm{Mn}_{2}(\mathrm{CO})_{8}\left(\mathrm{PPh}_{3}\right)_{2}
$$

of II in $\mathrm{CCl}_{4}{ }^{35}$. The plot of moles of IV against irradiation time, Figure 4 shows that the product is not a secondary product, and, in fact, i.r. spectra and mass balance at low conversion show that III is only a very minor reaction product. Substitution of two COs by one photon is most reasonably rationalized by the sequence in (40).

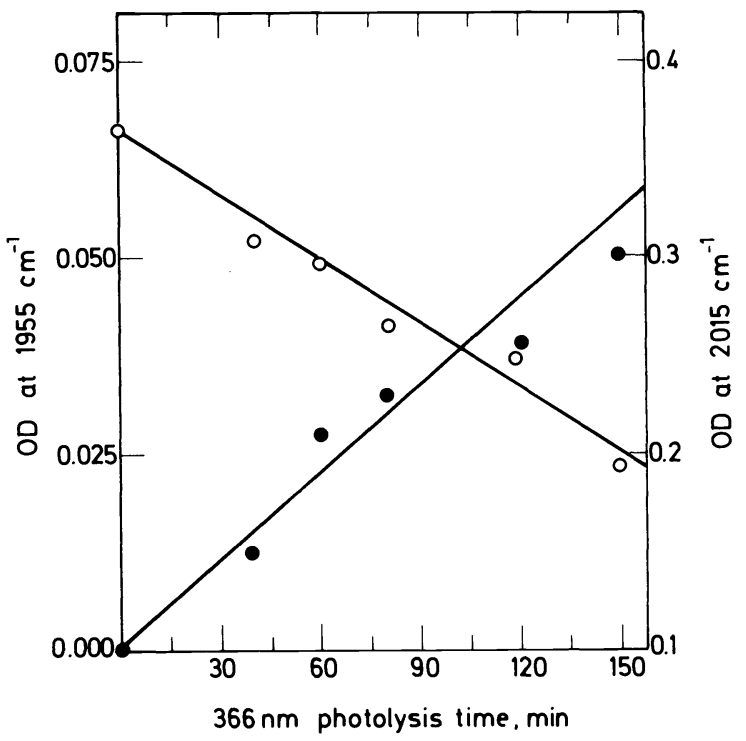

Figure 4. Plot of increase in optical density of the $1955 \mathrm{~cm}^{-1}$ i.r. absorption band of $\mathrm{Mn}_{2}(\mathrm{CO})_{8}\left(\mathrm{PPh}_{3}\right)_{2}$ (O and left scale) and decline of the $2015 \mathrm{~cm}^{-1}$ i.r. absorption band of $\mathrm{Mn}_{2}(\mathrm{CO})_{10}(\mathrm{O}$ and right scale $)$ against $366 \mathrm{~nm}\left(\sim 10^{-7} \mathrm{ein} / \mathrm{min}\right)$ photolysis time of a degassed isooctane solution of $\mathrm{Mn}_{2}(\mathrm{CO})_{10}\left(\sim 10^{-3} \mathrm{M}\right)$ in the presence of $\mathrm{PPh}_{3}$ at $0.1 \mathrm{M}$.

In summary, the photochemistry of the $\mathrm{Mn}$ and $\mathrm{Re}$ carbonyls containing a metal-metal bond is consistent with the qualitative predictions based on their electronic structure: metal-metal bond cleavage upon photoexcitation 
MARK S. WRIGHTON, D. S. GINLEY, M. A. SCHROEDER AND D. L. MORSE

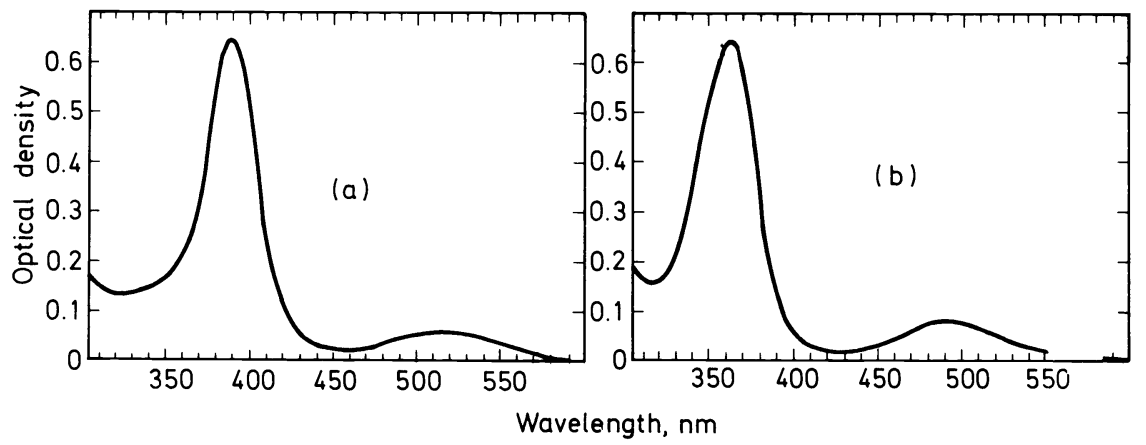

Figure 5. (a) Absorption spectrum of $\left(h^{5}-\mathrm{C}_{5} \mathrm{H}_{5}\right)_{2} \mathrm{Mo}_{2}(\mathrm{CO})_{6}\left(3.2 \times 10^{-5} \mathrm{M}\right)$ in $\mathrm{CCl}_{4}$ at $25^{\circ} \mathrm{C}$ in a $1.00 \mathrm{~cm}$ pathlength cell. (b) Absorption spectrum of $\left(h^{5}-\mathrm{C}_{5} \mathrm{H}_{5}\right)_{2} \mathrm{~W}_{2}(\mathrm{CO})_{6}\left(3.2 \times 10^{-5} \mathrm{M}\right)$ in $\mathrm{CCl}_{4}$ at $25^{\circ} \mathrm{C}$ in a $1.00 \mathrm{~cm}$ pathlength cell. The absorption near $500 \mathrm{~nm}$ is tentatively associated with the $\pi-d \rightarrow \sigma^{*}$ transition and the near-u.v. absorption with the $\sigma_{b} \rightarrow \sigma^{*}$ transition (see text).

in the near-u.v. is efficient and the resulting intermediates have some reactivity properties in common with their expected electronic analogue $\mathrm{Co}(\mathrm{CN})_{5}^{3-}$. We are now in a position to attempt to exploit this photochemistry to initiate catalysis.

Turning now to the Mo and W species, V and VI, we are faced with a very low symmetry problem. However, the electronic spectra of V and VI, Figure 5 , are very similar and, in a crude way, are similar to the spectra of $\mathbf{M n}_{2}$ $(\mathrm{CO})_{n}\left(\mathrm{PPh}_{3}\right)_{10-n}(n=10,9,8)$. The near-u.v. region is dominated by a
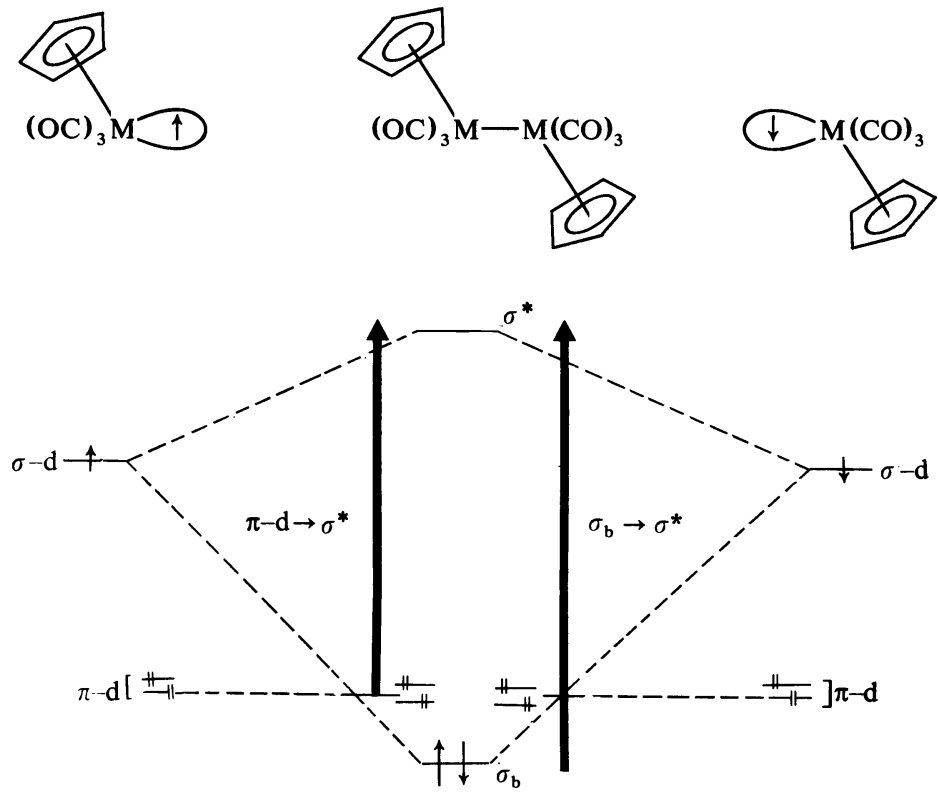

Scheme IV 


\section{CATALYSTS BY PHOTOLYSIS OF TRANSITION METAL COMPLEXES}

sharp, intense $\left(\varepsilon \approx 200001 . \mathrm{mol}^{-1} \mathrm{~cm}^{-1}\right)$ absorption and at lower energy a less intense maximum is found. We, thus, offer tentatively the $\sigma_{b} \rightarrow \sigma^{*}$ assignment to the higher energy, intense band and the $\pi-d \rightarrow \sigma^{*}$ assignment to the visible absorption according to Scheme IV. Photolysis at either absorption band should lead to $\mathbf{M}-\mathbf{M}$ bond cleavage by virtue of the destabilization resulting from population of the $\sigma^{*}$ level. The resulting mononuclear fragments are 17-electron paramagnetic species if homolytic cleavage obtains but will be of the $d^{5}$ electronic configuration rather than $d^{7}$ as in I-IV.

Photolysis of $\mathrm{V}$ and $\mathrm{VI}$ in degassed $\mathrm{CCl}_{4}$ solution proceeds according to equation (42) and quantum yields at 366,436 and $550 \mathrm{~nm}$ are summarized in Table 17. The modest decline in reaction quantum yield at the lower

Table 17. Quantum yields for reaction of $\left(h^{5}-\mathrm{C}_{5} \mathrm{H}_{5}\right)_{2} \mathrm{M}_{2}(\mathrm{CO})_{6}$ in $\mathrm{CCl}_{4}$

\begin{tabular}{cccc}
\hline $\mathrm{M}$ & $\mathrm{Irrdn} \lambda, \mathrm{nm}$ & $\Phi$ dis. $\mathrm{M}-\mathrm{M}^{\mathrm{a}}$ & formn $\mathrm{M}-\mathrm{Cl}^{\mathrm{b}}$ \\
\hline Mo & 550 & 0.35 & 0.77 \\
& 405 & 0.42 & 0.94 \\
$\mathrm{~W}$ & 366 & 0.45 & 1.03 \\
& 550 & 0.12 & 0.25 \\
& 366 & 0.21 & 0.41 \\
\hline
\end{tabular}

- Quantum yield for disappearance of starting metal-metal bonded complex; \pm 10 per cent.

${ }^{b}$ Quantum yield for formation of $h^{5}-\mathrm{C}_{5} \mathrm{H}_{5} \mathrm{M}(\mathrm{CO})_{3} \mathrm{Cl} ; \pm 10$ per cent.

excitation energies is consistent with the likelihood of lower reactivity of the $\pi-\mathrm{d} \rightarrow \sigma^{*}$ state compared to the $\sigma_{\mathrm{b}} \rightarrow \sigma^{*}$ state. Photolysis of V or VI in the presence of $\mathrm{Ph}_{3} \mathrm{CCl}$ yields the mononuclear metal carbonyl chloride and the

$$
\left[h^{5}-\mathrm{C}_{5} \mathrm{H}_{5} \mathrm{M}(\mathrm{CO})_{3}\right] \underset{\mathrm{CCl}_{4}}{\stackrel{h v}{\longrightarrow}} 2 h^{5}-\mathrm{C}_{5} \mathrm{H}_{5} \mathrm{M}(\mathrm{CO})_{3} \mathrm{Cl}
$$

e.s.r. detectable $\mathrm{Ph}_{3} \mathrm{C} \cdot$ radical. Further, photolysis of $\mathrm{V}$ in the presence of benzyl chloride in benzene gives an $\sim 88$ per cent yield of bibenzyl. Finally, reaction (43) proceeds in good chemical yield in benzene. The recently reported ${ }^{39}$ photogeneration of the metal carbonylanion $\left[h^{5}-\mathrm{C}_{5} \mathrm{H}_{5} \mathrm{Mo}(\mathrm{CO})_{3}\right]^{\ominus}$

$$
\left[\left(h^{5}-\mathrm{C}_{5} \mathrm{H}_{5}\right) \mathrm{Mo}(\mathrm{CO})_{3}\right]_{2}+\mathrm{Mn}_{2}(\mathrm{CO})_{10} \stackrel{h v}{\longrightarrow}\left(h^{5}-\mathrm{C}_{5} \mathrm{H}_{5}\right) \mathrm{Mo}(\mathrm{CO})_{3}-\mathrm{Mn}(\mathrm{CO})_{5}
$$

from $\mathrm{V}$ may be due to a secondary disproportionation reaction of the metal radicals subsequent to the photoinduced homolytic cleavage. A further possibility is that the primary photoprocess is very sensitive to the medium. The noteworthy result, though, is that the complexes V and VI undergo efficient $\mathbf{M}-\mathbf{M}$ bond cleavage consistent with the electronic state assignments in Scheme $I V$, and the mononuclear species generated participate in several interesting chemical reactions.

\section{SUMMARY}

Transition metal photocatalysis and photoassistance have been defined and some recent results in this area described. The CO photodissociation from 
$\mathrm{W}(\mathrm{CO})_{6}, \mathrm{Mo}(\mathrm{CO})_{6}, \mathrm{Cr}(\mathrm{CO})_{6}$, and $\mathrm{Fe}(\mathrm{CO})_{5}$ has been shown to lead to generation of intermediates capable of leading to synthetically useful catalytic reactions of olefins. Elucidation of primary photoprocesses in metal carbonylstyrylpyridine complexes has provided models for the study of photoassistance and new intramolecular electronic-excitation energy dissipation pathways. Efficient photogeneration of reactive mononuclear paramagnetic intermediates from inert dinuclear carbonyls has been shown to be the exclusive photoreaction for six complexes containing direct metal-metal bonds. The photochemistry of the metal-metal bonded compounds in the presence of alkyl halides suggests their potential use as photocatalysts.

\section{ACKNOWLEDGEMENTS}

Research support from the National Science Foundation and the Office of Naval Research is gratefully acknowledged. M.S.W. acknowledges support as an A. P. Sloan Foundation Fellow, 1974-1976. D.S.G. thanks the Department of Chemistry of the MIT for a Sloan Trainee Fellowship, 1973-1974, and MAS thanks the Department for an American Cyanimid Fellowship, 1974. M.S.W. thanks Professors H. B. Gray and G. S. Hammond for several stimulating discussions in the early stages of this work.

\section{REFERENCES}

1 F. A. Cotton and G. Wilkinson, Advanced Inorganic Chemistry, 3rd edition, pp 770-800. Interscience: New York (1972).

2 V. Balzani and V. Carassiti, Photochemistry of Coordination Compounds. Academic Press: New York (1970).

3 Organic Synthesis via Metal Carbonyls, Vol. I, edited by I. Wender and P. Pino. Interscience: New York (1968).

${ }^{4}$ For properties and synthesis of pyridyl complexes of $\mathrm{W}$ and Re cf.:

(a) F. Zingales, U. Satorelli and A. Trovati, Inorg. Chem. 6, 1246 (1967);

(b) F. Zingales, M. Graziani, F. Faraone and U. Belluco, Inorg. Chim. Acta, 1, 172 (1967);

(c) ref. 3, pp 167, 170-171, 231-233.

5 M. Wrighton, G. S. Hammond and H. B. Gray, Mol. Photochem. 5, 179 (1973).

${ }^{6}$ M. Wrighton, Inorg. Chem. 13, 905 (1974).

7 (a) P. P. Zarnegar, C. R. Bock and D. G. Whitten, J. Amer. Chem. Soc. 95, 4367 (1973);

(b) P. P. Zarnegar and D. G. Whitten, J. Amer. Chem. Soc. 93, 3776 (1971).

8 M. S. Wrighton, D. L. Morse and L. Pdungsap, J. Amer. Chem. Soc. 97, 2073 (1975) and unpublished results.

9 D. G. Whitten and M. T. McCall, J. Amer. Chem. Soc. 91, 5097 (1969).

10 M. Wrighton, Chem. Rev. 74, 401 (1974).

11 W. Jetz and W. A. G. Graham, Inorg. Chem. 10, 4 (1971).

12 (a) M. Wrighton, G. S. Hammond and H. B. Gray, J. Organometal. Chem. 70, 283 (1974);

(b) M. Wrighton, G. S. Hammond and H. B. Gray, J. Amer. Chem. Soc. 92, 6068 (1970); 93, 3285 (1971).

13 M. Wrighton and M. A. Schroeder, J. Amer. Chem. Soc. 95, 5764 (1973).

14 J. Nasielski, P. Kirsch and L. Wilputte-Steinert, J. Organometal. Chem. 27, C13 (1971).

15 (a) M. Cais, E. N. Frankel and R. A. Rejoan, Tetrahedron Letters, 1919 (1968);

(b) E. N. Frankel and F. L. Little, J. Amer. Oil Chem. Soc. 46, 256 (1969);

(c) E. N. Frankel and R. O. Butterfield, J. Org. Chem. 34, 3930 (1969);

(d) E. N. Frankel, J. Org. Chem. 37, 1549 (1972).

16 G. Natta, R. Ercoli, F. Calderazzo and E. Santambrozio, Chim. Ind. (Milan), 40, 1003 (1958).

17 M. S. Wrighton and J. L. Haverty, Z. Naturforsch B, in press (1975).

18 R. B. King and A. Fronzaglia, Inorg. Chem. 5, 1837 (1966). 


\section{CATALYSTS BY PHOTOLYSIS OF TRANSITION METAL COMPLEXES}

19 M. A. Schroeder and M. S. Wrighton, J. Organometal. Chem. 74, C29 (1974).

${ }^{20}$ M. S. Wrighton and M. A. Schroeder, J. Amer. Chem. Soc. 96, 6235 (1974).

21 D. Seyferth, T. F. Jula, H. Dertouzos and M. Pereyre, J. Organometal. Chem. 11, 63 (1968) and references cited therein.

22 (a) E. N. Frankel, E. A. Emken, H. M. Peters, V. L. Davison and R. O. Butterfield, J. Org. Chem. 29, 3292 and 3299 (1964);

(b) E. N. Frankel, E. A. Emken and V. L. Davison, J. Org. Chem. 30, 2739 (1965);

(c) M. Cais and N. Moaz, J. Chem. Soc. $(A), 1811$ (1971);

(d) N. Moaz and M. Cais, Israel J. Chem. 6, 32 (1968).

23 (a) P. S. Hallman, B. R. McGarvey and G. Wilkinson, J. Chem. Soc. (A), 3143 (1968);

(b) C. O'Connor and G. Wilkinson, J. Chem. Soc. 2665 (1968);

(c) M. G. Burnett and R. J. Morrison, J. Chem. Soc. (A), 2325 (1971).

${ }^{24} \mathrm{Fe}(\mathrm{CO})_{5}$ photoassisted olefin isomerizations have been reported previously and are reviewed and discussed in E. A. Koerner von Gustorf and F.-W. Grevels, Forschr. Chem. Forsch. 13, 366 (1969).

25 G. Cardaci and V. Narciso, J. Chem. Soc. Dalton, 2289 (1972).

26 (a) H. W. Sternberg, R. Markby and I. Wender, J. Amer. Chem. Soc. 79, 6116 (1957);

(b) F. Asinger, B. Fell and G. Collin, Chem. Ber. 93, 716 (1963).

27 E. W. Abel and F. G. A. Stone, Quart. Rev. 23, 325 (1969).

28 (a) G. L. Simon, A. W. Adamson and L. F. Dahl, J. Amer. Chem. Soc. 94, 7654 (1972);

(b) L. D. Brown, K. N. Raymond and S. Z. Goldberg, J. Amer. Chem. Soc. 94, 7664 (1972).

29 (a) J. Halpern and J. P. Maher, J. Amer. Chem. Soc. 87, 5361 (1965);

(b) P. B. Chock and J. Halpern, J. Amer. Chem. Soc. 91, 582 (1969).

30 A. A. Vlćek and F. Basolo, Inorg. Chem. 5, 156 (1966).

31 A. Haim and W. K. Wilmarth, J. Amer. Chem. Soc. 83, 509 (1961).

32 J. K. Kwiatek, Catal. Rev. 1, 37 (1967).

33 R. A. Levenson, H. B. Gray and G. P. Ceasar, J. Amer. Chem. Soc. 92, 3653 (1970).

34 M. Wrighton and D. Bredesen, J. Organometal. Chem. 50, C35 (1973).

35 M. S. Wrighton and D. S. Ginley, J. Amer. Chem. Soc. 97, 2065 (1975) and J. Amer. Chem. Soc., in press (1975).

36 (a) J. C. Kwok, Ph.D. Thesis, University of Liverpool (1971);

(b) K. Moedritzer, Syn. Inorg. Metal. Org. Chem. 1, 63 (1971);

(c) ref. $37 \mathrm{~d}$.

37 (a) G. O. Evans and R. K. Sheline, J. Inorg. Nucl. Chem. 30, 2862 (1968);

(b) W. Hieber, W. Beck and G. Zeitler, Angew. Chem. 73, 364 (1961);

(c) T. Kruck, M. Hofler and M. Noack, Chem. Ber. 99, 1153 (1966);

(d) W. Hieber and W. Schropp Jr, Z. Naturforsch. B, 15, 271 (1960).

38 (a) M. L. Ziegler, H. Haas and R. K. Sheline, Chem. Ber. 98, 2454 (1965);

(b) A. G. Osborne and M. H. B. Stiddard, J. Chem. Soc. 634 (1964).

39 A. R. Burkett, T. J. Meyer and D. G. Whitten, J. Organometal. Chem. 67, 67 (1974). 